\title{
After the fire: the end of a house life-cycle at the Iron Age site of Nabás (North-western Iberia)
}

\author{
MARÍA MARTín-SEIJO ${ }^{1}$, ANDRÉS TEIRA-BRIÓN ${ }^{1}$, ANDRÉS CURRÁS ${ }^{2}$, CARLOS \\ RODRÍGUEZ-RELLÁN ${ }^{1,3}$ \\ ${ }^{1}$ Grupo de Estudos para a Prehistoria do NW Ibérico-Arqueoloxía, Antigüidade e \\ Territorio, GEPN-AAT (GI-1534), Departamento de Historia, Universidade de \\ Santiago de Compostela, Praza da Universidade 1, 15782 Santiago de \\ Compostela, Spain, e-mail: maria.martin.seijo@gmail.com \\ ${ }^{2}$ Institute of Heritage Sciences (Incipit, CSIC), Avenida de Vigo, s/n, 15705 \\ Santiago de Compostela, Spain \\ ${ }^{3}$ Grupo ATLAS, Departamento de Prehistoria y Arqueología, Universidad de \\ Sevilla, María de Padilla s/n, 41004 Sevilla, Spain
}

\begin{abstract}
The existence of a fire event at the Iron Age hillfort of Nabás, which is located on the southern bank of the Ría de Vigo (Galicia, NW of the Iberian Peninsula), favoured an extraordinary preservation of carbonised plant remains and offered an unusual opportunity to focus our research on the study of the final episode of a house life-cycle.

The archaeobotanical approach focused on perishable materials combining charcoal, with carpology and pollen analysis, in tandem with a taphonomic assessment. The charcoal assemblage includes charcoal without signs of working, and wooden manufactures although the former group was probably related to the roof and timber of the roundhouse. This interpretation is based on the size and concentration of charcoal fragments, as well as the short taxonomic list (deciduous and evergreen Quercus sp., Fabaceae, Corylus avellana, Rosaceae/Maloideae, Salix/Populus, Alnus sp., Frangula alnus, Betula sp., Phragmites/Arundo and Ulmus sp.), and the recurrence of biological alterations such as xylophages' galleries and hyphae. Aggregated grains and chaff of foxtail millet (Setaria italica) were found in several samples suggesting their storage, probably inside an organic container. Finally, pollen analysis offered clues about the uses of plants such as Ericaceae during the occupation phase of the round-house.
\end{abstract}

Keywords Charcoal analysis - Wooden manufactures - Seed analysis · Palynology $\cdot$ Burnt-down house $\cdot$ Iron Age 


\section{Introduction}

\section{Aim and objectives}

The contact of fire with plant remains favours their preservation by carbonisation in the absence of oxygen, or by charring, with a limited air supply when the combustion process is not complete (Braadbaart and Poole 2008). In Iron Age contexts of Northwest Iberia, this usually happened during the use of fire for processing or consuming crops and fruits (e.g. Tereso 2012; Teira 2019), while burning firewood, discarded wooden items or wood-working debris (e.g. MartínSeijo 2008; Vaz et al. 2017), during the intentional destruction of food and wooden objects by fire in feasting contexts (e.g. Tereso and Silva 2014; MartínSeijo et al. 2015), or during fire events that took place inside the settlements (e.g. Figueiral 1995; Cobas and Parcero 2006; Rey et al. 2011; Queiroga 2015). Carbonised plant remains have been frequently recovered from archaeological sites when an adequate recovery strategy has been adopted (e.g. Figueiral 1995, 1996; Carballo 2002; Rey et al. 2011; Tereso et al. 2013b, 2016; Vaz et al. 2017), and they include a growing body of wooden manufactures, such as building elements, domestic, artisanal and ritual objects, household equipment or weapons (García-Rollán 1971; Almeida et al. 1980; López-Cuevillas and LorenzoFernández 1986; Orero 1988; Carballo 2002; Cobas and Parcero 2006; Vigo 2007 [not in refs]; Martín-Seijo 2008, 2013; Martín-Seijo and Carballo 2010; Rey et al. 2011; Martín-Seijo and Carrión 2012; Martín-Seijo et al. 2015).

The role of fire during the Iron Age went further than practical uses and applications in the domestic and specialised spheres; its symbolic meaning was related to material evidence such as the presence of decorated hearths inside the houses (e.g. Silva 1986), and with practices involving the destruction of objects by fire (e.g. Martín-Seijo et al. 2015). In burnt-down houses, their last stage of occupation is frequently preserved, providing valuable information that deepens our understanding about the daily life of these communities (Tringham 2005). It is possible to recover information about spatial organisation of day-to-day activities, material culture patterning, including both perishable and non-perishable materials, as well as architectural techniques (wooden frames, wooden joints, thatching materials etc.). In the case of accidental fires, one or more of the following factors may have been at play: (1) houses located in close proximity; 
(2) storage of grain that increases the possibility of spontaneous combustion; and/or (3) storage of textiles and other combustible materials furnishing the house (Tringham 2005, 2013). In the case of being intentionally set alight, it could be a purposive (and planned) destruction induced by the members of the community who inhabited the settlement, or it could be part of an attack or aggression by outsiders. To identify the existence of an intentional firing of a house, several factors must be taken into account: the scale of the fire; the stage of the use-life of the house; and the associated artefacts, including the presence of deliberate or structured depositions (Tringham 2013), although the ultimate aim of these gestures [activities?] involving material culture patterning is difficult to ascertain (Garrow 2012).

One of the approaches to these kind of context is the study of the life-cycles of houses (and settlements) that were addressed in other Bronze and Iron Age sites of Western Europe (Brück 1999; Gerritsen 1999, 2007, 2008; Webley 2007) and the Iberian Peninsula (e.g. Blanco-González 2011; Sánchez-Polo and BlancoGonzález 2014), and this is based on the application of the perspective of time and temporality to the study of the household (Gerritsen 2008). Biographies of single houses have not yet been addressed in Northwest Iberia, despite the fact that the cultural life of houses could provide interpretative hypotheses about different stages of their lifecycle, which involve construction, habitation, abandonment and post-abandonment (Brück 1999; Gerritsen 1999). The burnt-down round-house of Nabás offered the unusual opportunity (1) to reflect upon the strategies of sample gathering in contexts where fire events took place, (2) to discuss the procurement and uses of wood and other plant materials developed by these communities, (3) to define the chaîne-opératoire of the crop processing, and finally, (4) to study the end of the life-cycle of this Iron Age round-house combining different archaeobotanical proxies, taphonomy and contextual data. These four topics were the main goals of our research.

\section{Archaeological background}

During the Iron Age in Northwest Iberia, between the ninth century BC to the second-first century BC (Jordá-Pardo et al. 2009), settlements were occupied permanently for the first time in local history (Parcero and Cobas 2004). These were small hillforts located on promontories and enclosed by artificial structures 
such as ditches and ramparts. Later in time, under Roman occupation, large oppidum-type settlements up to 20 ha begin to appear (Silva 1986; Parcero 2003). During the Iron Age, differences have been identified regarding the settlement patterns (Carballo 1990), as well as changes in architectural features (Carballo 1996) and households (Romero 1976). Round-houses - a type of building with circular plan and a habitational or occupational function that was common in the Atlantic areas of Europe - were a key feature in the Northwest of the Iberian Peninsula (Harding 2009), including both huts made completely from perishable materials or houses built with stone walls and thatched roofs (Harding 2009; Queiroga 2015).

The settlement pattern shift leading to permanent occupations in fortified settlements took place in tandem with transformations in both the social organisation and the productive landscape, which, in turn, were linked to a number of changes, including the establishment of permanent agricultural fields in the surroundings of the settlements (e.g. Parcero 2006). Overall, hulled wheats predominate in the archaeobotanical assemblages of northwest Iberia at the end of the first millennium BC, together with Panicum miliaceum (broomcorn millet), Hordeum vulgare ssp. vulgare (hulled barley) and Avena sp. (oat) (Tereso et al. 2013b). Radiocarbon dates recently obtained for Triticum aestivum ssp. spelta (spelt), Avena and Secale cereale (rye) suggest an early introduction of new crops in this area (Tereso et al. 2013b; Seabra et al. 2018). The presence of winter and spring cereals, accompanied by legumes as main cultivars, indicates that each year these communities grew two crops of species well adapted to variable and harsh environmental conditions, while wild fruit gathering continued to play a crucial role (Teira 2010; Rey et al. 2011; Tereso et al. 2013a, b; Seabra [et al.?] 2018). The data available nowadays indicate that the organisation of the agricultural resources and the storage facilities was probably related to a family management system (Tereso et al. 2013b; Mora-González et al. 2019).

In line with these changes, the trend of progressive woodland retreat continued during the first millennium BC (Gómez-Orellana et al. 1996; Muñoz Sobrino et al. 2014), with a synchronous development of heathland communities of Erica, Calluna, Cistus and Ulex (Muñoz-Sobrino et al. 2012, 2014, 2016). According to the available pollen data, the forest canopy was dominated by deciduous Quercus trees, Corylus avellana shrubs and mesic genera such as Alnus, Betula and Salix. 
After $500 \mathrm{cal} \mathrm{BC}$, the occurrence of human-related taxa becomes more frequent, a process that is coeval with evidence of erosive dynamics that has been linked to the development of forest clearances resulting from human activities (FábregasValcarce et al. 2003; Muñoz Sobrino et al. 2012). Pollen analysis of marine and intertidal quaternary sedimentary deposits (Gómez-Orellana et al. 1996; Desprat et al. 2003; Muñoz Sobrino et al. 2007, 2012, 2014, 2016; Costas et al. 2009) provides an insight into the vegetation history of southwest Galicia during the Holocene, but precise information on vegetation evolution during the first millennium $\mathrm{BC}$ and the beginning of the first century AD is not abundant due to chronological uncertainties and lack of data. Regarding wood resource management, the human communities that inhabited the northwest of the Iberian Peninsula during the Iron Age combined the exploitation of woodland, riparian forests and scrubland for firewood and timber procurement in a diversified strategy of wood resource supply (Figueiral 1995; Figueiral and Bettencourt 2004; Martín-Seijo 2013). The co-occurrence of Quercus and Fabaceae in the charcoal assemblages of this area, which has been recorded since at least the Early Bronze Age (Figueiral and Bettencourt 2004; Martín-Seijo et al. 2017a, b), has been interpreted as a consequence of woodland clearance as well as an intentional management of scrubland resources (Figueiral and Bettencourt 2004). During the Iron Age, wood and other woody plants were extensively used as raw material for crafting all kinds of tools, recipients [containers?] and implements, and even logboats (Carballo 2002; Cobas and Parcero 2006; Alves and Rieth 2007; MartínSeijo 2008; Martín-Seijo and Carballo 2010; Rey et al. 2011; Martín-Seijo and Carrión 2012; Martín-Seijo 2013; Martín-Seijo et al. 2015), as well as being used for building and roofing round-houses (Figueiral 1995).

\section{Materials and methods}

\section{Case study [Study Site?]}

Nabás (Nigrán, Pontevedra) is located at 230 m a.s.l. in Monte de Outeiro Grande, along the southern margin of the Ría de Vigo (Northwest Iberia) (Fig. 1). This small fortified settlement occupied an area of ca 1.94 ha. Since 1989, several archaeological investigations have taken place on the site. The first archaeological investigations led to the delimitation of the settlement area, the definition of its 
wall and ditch, and the excavation of several stone buildings (Costas et al. 1996; Sigüenza 1998). In 2006, a circular stone building (Structure 01), which had previously been identified and partially excavated, was evaluated and excavated in Sector 1 (Figs. 2a and 2c). Some of the Stratigraphic Units (SU) recorded within this house include the inward collapse of the building's wall (SU06), which sealed a layer with charred botanical remains, clay and stones (SU12) and a concentration of charcoal remains (SU18). The house floor (SU13) and the hearth (SU17) were identified just beneath these deposits (Fig. 2c). The most recent archaeological investigation, which included the excavation in 2007 and 2008 of test-pits as well as open-area excavation, led to the identification of similar stratigraphic sequences, including charcoal-rich layers, within other circular stone buildings on the site.

When compared to other Iron Age settlements of the Ría de Vigo (e.g. Rey 1992; Rey et al. 2009), there was a notable scarcity of ceramic, lithic and metal objects at Nabás, which contrasts with the huge amount of charred archaeobotanical remains that were preserved. All the stone buildings presented a high level of destruction. The site appears to have had a single phase of occupation between the second century BC and the first century AD, which is supported by two radiocarbon dates (Table 1) and by artefact typology, such as the Lomba do Canho 67 amphora that dates to the first century BC (Rodríguez-Sáiz 2010).

\section{Sample recovery and processing}

As part of the excavation in 2006, an extensive programme of sampling for recovering macro- and micro-botanical remains was undertaken. The retrieval strategy consisted of collecting both handpicked and bulk samples from all the stratigraphic units. Due to the high concentration and large size of charcoal identified in SU12 and SU17, handpicked samples were recovered exhaustively and systematically to avoid post-excavation fragmentation. The absolute coordinates of each sample were recorded. These coordinates correspond to the centre of a circumference with a radius measuring ca $0.2 \mathrm{~cm}$. In a few cases only one piece was recovered per sample. Ninety-five litres of sediment from bulk samples were processed by wet sieving using meshes of 2 and $1 \mathrm{~mm}$, and 0.48 litres of sediment were wash-over sieved using meshes of 2,1 and $0.5 \mathrm{~mm}$. The $0.5 \mathrm{~mm}$ meshes were used to process only $5.1 \%$ of the sediment recovered, which 
must have conditioned the composition of the carpological assemblage, precluding the recovery of small-seeded wild herbs and weeds, although in Nabás, carpological remains were recovered in monospecific aggregates or related to them, as well concentrated near the hearth of the round-house. One column of 12 samples was also recovered for pollen analysis inside Structure 01, from the profile formed by the paved floor and the underlying deposits.

\section{Archaeobotanical analysis}

\section{Charcoal analysis}

Charcoal analysis involved taxonomic identification, in tandem with the recording of dendrological and taphonomical attributes of 1,654 charcoal fragments from 26 samples. All wood charcoal fragments greater than $3 \mathrm{~mm}$ were analysed, only seven samples (handpicked samples: 16, 18 and 23 and water sieved samples: 03, 07, 24 and 26) were sub-sampled due to the great quantity of charcoal that they contained (ESM Table 1). In these cases, between 100 and 158 fragments were analysed, depending on their botanic diversity. A minimum of 100 fragments was analysed, enlarging the number of fragments until the taxonomic curve was stabilised, following Chabal (1997). Each fragment was observed using an Olympus CX40 reflected-light microscope and taxonomically identified according to the specific anatomical patterns on the three sections of wood - cross, tangential and radial. The identifications were based on wood anatomy atlases and their identification keys (Schweingruber 1990; Gale and Cutler 2000; Hather 2000). Charcoal photographs were obtained using an Olympus SZX7 stereoscopic microscope and a ZEISS EVO LS 15 Scanning Electron Microscope. Taphonomic and dendrological attributes were recorded with the aim of approaching the different processes involved in the formation of an archaeobotanical assemblage. Their exhaustive description completes the taxonomical data and could help in the characterisation of the kind of wood resources that were managed (part of the plant, calibre and maturity of wood), the combustion process (vitrification, cracks), the state of the wood before burning (biodeterioration) and the depositional and post-depositional processes (fragmentation, erosion) (RodríguezAriza 1993; Théry-Parisot 2001; Marguerie and Hunot 2007; Schweingruber 2007; Braadvaart and Poole 2008; Schweingruber et al. 2008; Lancelotti et al. 
2010; McParland et al. 2010; Moskal del Hoyo et al. 2010; Théry-Parisot and Henry 2012; Martín-Seijo 2013; Chrzazvez et al. 2014).

\section{Wooden manufactures: morphometric analysis and study of the technical process}

Traces of crafting were observed in nine of the analysed charcoal fragments. These manufactured pieces were studied at the macroscopic level, analysed morphometrically, and described and drawn in situ during excavation. To study the technical process behind their production, the concept of the chaineopératoire was employed as it facilitates the organization and description of the sequence of actions involved in the production process: raw material procurement, support conversion, product preparation and final product. This concept considers a production process as a sequence of actions influenced by technical possibilities and personal and cultural choices (Skibo and Schiffer 2008). The morphotechnological analysis of each wooden piece enabled the correlation of acquisition and manufacture techniques with the raw materials and the morphological design of the objects. The reduction process of the piece from the stem was also recorded using codes to classify the different types of extraction from the original support (Martín-Seijo 2013), combining various schemes previously published (Coles et al. 1978; Crone and Barber 1981; Shackley [1981 not in refs or 1985?]; Coles and Coles 1986; Vermeeren 2001; Pillonel 2007): complete stem with the bark (A), radial (B to I), longitudinal ( $\mathrm{J}$ to $\mathrm{Q}$ ) or irregular (R to U) splitting, bark (F) and indeterminate extractions $(\mathrm{V})$.

\section{Seed analysis}

185,198 carpological remains were recovered from 6 samples. Their identification was carried out using a stereoscopic microscope and by comparing the botanical remains to atlases (Jacomet 2006; Neef et al. 2012) and to the reference collection of the GEPN-AAT (Grupo de Estudos para a Prehistoria do NW IbéricoArqueoloxía, Antigüidade e Territorio), which includes actual samples gathered during an ethnobotanical fieldwork project (Moreno-Larrazabal et al. 2015). Seed sub-sampling and counting was carried out by sorting two samples of 1/8 and 1/16 of the total remains. In the case of crusts, weight per sample was measured because counting single grains was not possible. SEM images were obtained to 
record the morphology of seed and fruits as well as other plant characteristics, such as state of preservation, vitrification, erosion etc.

\section{Pollen analysis}

Inside Structure 01, a $50 \mathrm{~cm}$ thick sedimentary profile, which was produced during the excavation of 1991 and refreshed in 2006, was used to collect samples for palynological analyses. The upper part of this profile corresponds to the occupation floor, with infilling sedimentary deposits below (Figs. 2b and 2c). Though this profile was not adequate to obtain a diachronic view of the vegetation succession around the site, it was selected for pollen analysis in order to understand the formation processes of the occupation floor and the underlying deposits. A total of 12 samples were collected, each roughly $5 \mathrm{~cm}$ in depth, numbering from 1 (most recent) to 12 (oldest). The main changes as seen in the profile were noted with the aim of analysing the preserved fossil pollen and inferring possible vegetation associated with the provenance of the sediment at the time of the construction of the structure. The sample number according to depths in the profile is displayed in Fig. 2b and ESM Table 2.

The sedimentary samples were treated following standard pollen preparation procedures, which included $\mathrm{HCl}$, sieving at $200 \mathrm{~m}, \mathrm{HF}, \mathrm{KOH}$, acetolysis and mounting in glycerine (Fægri and Iversen 1989). Pollen and non-pollen palynomorphs (NPP) were counted and identified at $\times 400$ magnification by reference to published illustrations and morphological keys (Reille 1992-1998; van Geel 2001). The determination of Cerealia pollen was carried out according to Andersen (1979). Pollen and NPP diagrams were constructed by plotting relative frequencies in percentages of taxa against the sample number according to the stratigraphic units. Pollen percentages were calculated as percentages of total land pollen, excluding aquatic plants, spores and undetermined palynomorphs. NPP percentages were calculated by reference to total land pollen (Blackford et al. [and Innes?] 2006). Biozones were established according to stratigraphically constrained incremental sum of squares cluster analysis (Grimm 1987), so that the main changes in the pollen assemblage could be identified. Palynological indicators of human activity and dung-related spores were defined from the literature (Behre 1981, 1986; Bottema and Woldring 1990; van Geel and Aptroot 2006; Ejarque et al. 2009, Cugny et al. 2010). 


\section{Statistical analysis of the charcoal data}

The statistical analyses of charcoal data were conducted in $R$, version 3.5.1 ( $R$ Core Team 2018), using, among others, packages such as 'vegan', which provides tools for descriptive community ecology (Oksanen et al. 2018). To test the strategy of recovery undertaken during the archaeological excavation, the charcoal analysis data provided by handpicked and bulk samples were analysed in order to compare between them the ubiquity of the different taxa (number of samples containing a specific taxon), the species richness (number of taxa per sample) and other diversity indices, such as Shannon's diversity, Simpson's diversity and Pielou's J evenness index (Borcard et al. 2011; Greenacre and Primicerio 2013). The two different strategies of sample recovery were statistically compared by means of parametric (Student's t) and non-parametric (Mann-Whitney-Wilcoxon) tests in order to check if there were any significant differences between both methods regarding taxa composition or diversity. Finally, two different approaches were implemented in order to explore the relationship between richness and sample size and to detect if the variability in diversity detected in the samples was simply due to their different size or if there might be other causes behind such variation. Linear and nonlinear regression models were first compared in order to estimate the richness for any sample size. Monte-Carlo prediction/confidence intervals were created for these models using the data of 100,000 simulations. Rarefaction curves and their $95 \%$ confidence intervals were then calculated.

\section{Results}

\section{Charcoal assemblage}

\section{Charcoal identification}

The majority of the charcoal fragments did not show clear evidence of manufacture $(\mathrm{N}=1,645)$. The identification outcomes are summarised in Tables 2 and 3, and the results of the statistical analysis are presented in ESM A and B. In total, 13 taxa were identified: deciduous Quercus sp., evergreen $Q$. sp., Q. suber (cork), Q. sp., Corylus avellana (Figs. 3c, 3d), Fabaceae, Phragmites/Arundo (Figs. 3g, 3h), Rosaceae/Maloideae, Alnus sp. (Figs. 3a, 3b), Betula sp., 
Salix/Populus, Ulmus sp. (Figs. 3e, 3f) and Frangula alnus. These taxa were gathered from different plant communities, such as mixed deciduous forests dominated by oak (deciduous Quercus, Corylus avellana, Rosaceae/Maloideae) with a presence of evergreen vegetation (evergreen $Q ., Q$. suber), scrubland (Fabaceae), alluvial forests and wetland communities (Alnus sp., Betula sp., Salix/Populus, Ulmus sp., Frangula alnus, Phragmites/Arundo) (Amigo et al. 2017).

\section{Dendrological attributes and taphonomic features}

The part of the plant was morphologically identified in 96 charcoal fragments (Table 4), 78 of which were from twigs of Fabaceae, Corylus avellana, deciduous Quercus sp. and Alnus sp. The diameter was measured in 25 fragments that preserved pith and bark, or had a complete stem (Table 5). Several alterations related to the growing conditions of the tree were identified, such as narrow rings (Fig. 4a), which were recorded in deciduous Quercus sp. (N=7), or scars (Fig. 4b), which were recorded in Quercus, both deciduous $(\mathrm{N}=6)$ and evergreen $(\mathrm{N}=5)$, and Corylus avellana $(\mathrm{N}=2)$. The biological action of insects and microorganisms was identified by the presence of galleries of xylophages (Fig. 4c) and hyphae (Fig. 4d). Galleries of xylophages were observed in 77 fragments, most of them from SU12 and SU18 where the percentage of charcoal affected by xylophages reached $3.73 \%$ and $12 \%$ respectively, while in SU17 $3.07 \%$ of fragments were affected. In SU12 and SU18, the galleries were observed in deciduous Quercus sp. (N=46), Corylus avellana $(\mathrm{N}=15)$, Fabaceae $(\mathrm{N}=4)$, evergreen Quercus sp. $(\mathrm{N}=4)$, Quercus sp. $(\mathrm{N}=2)$, Betula sp. $(\mathrm{N}=1)$ and Ulmus sp. $(\mathrm{N}=1)$; while in $\mathrm{SU} 17$, only Quercus sp. deciduous $(\mathrm{N}=2)$ and Corylus avellana $(\mathrm{N}=2)$ were affected. The presence of hyphae affected $1.76 \%$ of charcoal. Fungi filaments were observed in the following taxa: Quercus sp. deciduous $(\mathrm{N}=13)$, Fabaceae $(\mathrm{N}=4)$, Corylus avellana $(\mathrm{N}=7)$, evergreen Quercus sp. $(\mathrm{N}=2)$, Phragmites/Arundo $(\mathrm{N}=1)$, Betula $\mathrm{sp} .(\mathrm{N}=1)$ in SU12 and SU18 and Quercus sp. deciduous $(\mathrm{N}=1)$ in SU17.

Alterations related to the combustion process were also identified. With $25.16 \%$ of fragments affected, radial cracks were the most frequent of these combustion alterations, followed by vitrification $(5.34 \%)$, tangential cracks $(0.72 \%)$ and arbitrary cracks $(0.06 \%)$. These alterations were observed mostly in Quercus sp. deciduous and Fabaceae (Fig. 5). In SU12, it was possible to compare the tree- 
ring curvature of three taxa: Quercus sp. deciduous, Corylus avellana and Fabaceae (Fig. 6). Strong and moderate tree-ring curvatures predominate in all of them, and weak curvatures were only identified in Quercus sp. deciduous.

Charcoal fragmentation varies between bulk and handpicked samples, as is shown in SU12 (Fig. 7). If it is assumed that handpicked samples have preserved their original size, $91.03 \%$ of fragments range up to $0.5-3 \mathrm{~cm}$, including $2.96 \%$ of up to 3-6 cm. The selection of the biggest pieces of charcoal by handpicking and the sieving process resulted in a higher fragmentation of charcoal from bulk samples, with $86.52 \%$ of charcoal fragments ranging from $0.3-1 \mathrm{~cm}$. In all the samples, charcoal showed fresh fractures which can be considered signs of recent fragmentation, probably related to the process of excavation, sampling and storage. Charcoal fragments with evidence of erosion, such as rounded edges, were very infrequent in the assemblage $(\mathrm{N}=4)$ and were only identified in SU12. These fragments, all of which came from bulk samples, represent only $0.3 \%$ : Quercus sp. ( $\mathrm{N}=2)$, evergreen Quercus $\mathrm{sp}$. $(\mathrm{N}=1)$ and Corylus avellana $(\mathrm{N}=1)$.

\section{Carbonised woodcrafts}

All the charcoal fragments with evidence of manufacture were final products of the woodworking chaîne-opératoire. All of them were found within the hearth (SU17), where they were mixed with wood without signs of crafting and which was intentionally used as fuel (Figs. 8a to 8c). Wood selected for woodworking was obtained from deciduous Quercus sp. ( $\mathrm{N}=5)$ and evergreen $Q$. sp. $(\mathrm{N}=2)$; and cork from $Q$. suber $(\mathrm{N}=1)$ (Table 6). The extraction from the original support was by tangential or radial splitting from the trunk $(\mathrm{N}, \mathrm{O}, \mathrm{P})$ in the case of Quercus spp. planks, and by removing the bark from the trunk $(\mathrm{E})$ or using the bark $(\mathrm{F})$ in $Q$. suber. The function of each object was established on the basis of their morphological attributes. Seven crafted items were classified as planks (3893, 3894, 3902, 3903, 3904, 3905 and 3906), five of which were of deciduous Quercus sp. and the other two of evergreen $Q$. sp. The item classified as a hooklike object was made of deciduous Quercus sp. wood.

\section{Carpological remains}

Results of carpological analysis are summarised in Table 7. Foxtail millet (Setaria italica) was predominant in the assemblage and only one seed of Hordeum 
vulgare was identified. The greatest concentration of carpological remains was recorded within the hearth or in its immediate surroundings. The Setaria assemblage partially preserved palea and lemma stock on the seed, chaff remains and incomplete stems (Fig. 9). Foxtail millet fruits appeared as single grains or held together forming a crust in 4 samples. The grains of crusts were preserved complete with their covers (paleas and lemmas) attached to the caryopses and fragments of stems, with the contact surfaces between grains vitrified. Single grains appeared mainly as naked caryopses, but also seeds with adhered paleas or chaff were identified in smaller percentages.

\section{Pollen data}

Three biozones (Fig. 10) were established according to cluster analysis:

Biozone CN3 (samples 12 to 8). This records the highest frequencies of tree pollen. This is most apparent in samples 12, 11 and 10, in which deciduous Quercus reaches percentages around $30 \%$ and $40 \%$, whereas there are lower frequencies in samples 9 and 8. Other tree species such as Corylus avellana, Populus, Betula and Alnus were identified. A minor presence of Castanea sativa pollen is observed in sample 11. Noticeable percentages of Ericaceae pollen (ca $12 \%$ ) are recorded and these species exhibit a $38 \%$ peak in sample 12 . Poaceae pollen is present throughout biozone $\mathrm{CN} 3$ but does not exceed $20 \%$ representation. Other herb pollens such as Asteroideae, Cichorioideae, Caryophyllaceae and Asphodelus are present, usually below 10\%. Human-related Plantago lanceolata and Papaver rhoeas pollen types were also noted. One single Cerealia pollen grain was found in sample 11. Among the NPP, Sporormiella is recorded in samples 10 and 9;

Biozone CN2 (samples 7 to 3). This shows similar percentages of Corylus and Populus to those observed in CN3. Deciduous Quercus pollen, however, is recorded in lower percentages and does not exceed $15 \%$ representation. Occurrence of Ericaceae pollen is slightly higher throughout this biozone. Poaceae dominates among the herb pollen with percentages near 35\% in all the samples, higher than in $\mathrm{CN} 3$, except for a decline in sample 5. Other herb taxa present in $\mathrm{CN} 3$ have been recorded but there is further occurrence of Brassicaceae, Apiaceae and Artemisia, which evidences an overall higher representation of herbs in this biozone. The presence of Plantago lanceolata-type, 
Rumex and Papaver rhoeas type is also reported. A minor presence of Cerealia pollen was also observed in sample 3.

Biozone CN1 (samples 2 and 1). No pollen of deciduous Quercus was found, but undifferentiated Quercus, Corylus and Alnus was recorded. Pinus pollen, also present in biozone $\mathrm{CN} 2$, is higher in biozone $\mathrm{CN} 1$. Castanea pollen is furthermore observed in both samples. Ericaceae occurs at higher levels within the pollen assemblage, reaching a peak of nearly $60 \%$ of representation in sample 2 . The occurrence of herb pollen taxa is similar to that reported in previous biozones. Asphodelus is however absent now. It is noteworthy to indicate the presence of several human-related pollen taxa, such as Plantago lanceolata-type (12\%), Rumex and Cerealia in Sample 1.

\section{Discussion}

\section{Sample strategy inside the burnt-down house}

Following the broad definition of taphonomy proposed by Théry-Parisot et al. (2010), which starts with wood gathering and ends with archaeobotanical analysis, the discussion will examine the archaeobotanical filters introduced by sample gathering. The statistical analysis implemented for charcoal samples recovered at Nabás had the aim of testing the strategy of sample recovery (ESM A and B). The combination of handpicked and bulk sampling, with priority given to the former, was conditioned by the need to avoid fragmentation during the post-excavation process. This combined strategy during the excavation process is crucial in contexts where high concentrations of charcoal and evidence of wooden manufactures have been identified, such as in stratigraphic units SU12, SU17 and SU18. Handpicking charcoal avoids fragmentation produced during storing and processing samples, which could modify the percentages of different taxa. It could result in an overrepresentation of those taxa that produce the biggest pieces and even prevent the identification of manufactured wooden items due to their excessive fragmentation and loss of their original morphology.

Percentage differences between bulk and handpicked samples were detected in SU12 (Fig. 7). Higher percentages of Fabaceae and Corylus were identified in handpicked samples, whilst deciduous Quercus is better represented in charcoal fragments ranging from $0.3-10 \mathrm{~cm}$ from bulk samples. These differences are 
probably related to the diverse patterns of fragmentation between taxa. Deciduous Quercus is probably over-represented in bulk samples due to its tendency to radial fragmentation, and favoured also by the presence of radial, tangential and arbitrary cracks (Fig. 5). Whereas in the case of Fabaceae and Corylus, their resistance to fragmentation could be related to the fact that branches and twigs would be less prone to fragmentation. In both taxa the tree-ring curvatures identified range from strong to moderate (Fig. 6).

Regarding taxa representation at Nabás, the main differences between samples are conditioned by sample size, but no differences dependant on recovery method were attested in the larger samples ( $\ 99$ fragments) (Figs. 1 and 2. ESM A). Though 1,654 charcoal fragments were analysed, only a short taxonomic list was identified, which could be related to the formation processes of the archaeobotanical assemblages rather than the recovery strategy employed. At other Iron Age sites in Northwest Iberia where similar fire events have been identified, short taxonomic lists were also recorded: Alto do Castro (Cobas and Parcero 2006), Castrovite (Martín-Seijo and Carballo 2010; Rey et al. 2011), As Laias (Carrión 2005), Frijão (Martín-Seijo et al. 2015) or Penices (Figueiral 1995; Queiroga 2015). The highest taxonomic diversity (7 and 6 taxa) was identified in samples recovered from SU12, which also had a higher concentration of charcoal fragments, whilst SU17 and SU18 presented lower taxonomic variability. If it is assumed that most of the charcoal recovered from SU12 originally belonged to the supporting framework of the roof and the thatching material, the predominance of Quercus in most of the samples could be related to its use as structural timber (Fig. 11). Spatial differences in taxonomic diversity between samples in SU12 could thus be related to the different elements of the roof: the wooden rafters were probably more resistant to their exposure to the fire (samples with predominance of Quercus and low diversity) than other elements such as the wickerwork structure or the plants used for thatching. In the areas where these latter elements have been preserved, a greater diversity and the presence of small twigs and plant stems was identified (e.g. Samples 14, 15 and 16).

\section{Procurement and uses of wood and other plant materials}

The co-occurrence of the same taxa in charcoal and pollen samples indicates that wood resources were probably gathered in the environs of the site. These human 
communities developed a diversified exploitation of local resources that involved the use of tree-species such as deciduous and evergreen Quercus mixed with shrubs such as Fabaceae or Corylus avellana. Wood and wild plant resources were gathered from different plant formations, e.g. deciduous Quercus woodlands with thermophilous species, alluvial forests and scrublands. The importance of riverine forests or wetlands should also be highlighted, as, although taxa related to these plant communities are always represented by a low number of fragments, a great diversity of plants, such as Alnus sp., Betula sp., Salix/Populus, Ulmus sp., Frangula alnus and Phragmites/Arundo, were gathered from these plant communities.

The diversified exploitation of the environment, as well as the co-occurrence of deciduous Quercus and Fabaceae wood in the charcoal assemblages, is common in the Iron Age sites of northwest Iberia (Figueiral 1995; Figueiral and Bettencourt 2004; Martín-Seijo and Piqué 2013; Martín-Seijo 2013). While this combined exploitation could be interpreted as a side effect of woodland clearance, the spread of Fabaceae could also have been favoured by Iron Age communities (Figueiral and Bettencourt 2004) seeking to procure firewood, fodder, stable-litter and building material, while at the same time regenerating the soil through nitrogen-fixing. The complexity of forest and scrubland management developed by the Iron Age communities of northwest Iberia has also been attested by the identification of silvicultural practices such as Corylus coppicing to obtain raw materials for wattle-hurdling or basketry (Martín-Seijo and Carballo 2010) and Quercus suber bark harvesting (Martín-Seijo 2013).

Plant-based manufactures (several planks, a hook-like piece and a fragment of cork) were identified within the hearth (SU17) and were probably burned as firewood. Although the identification of crafted items intentionally burned has been previously recorded at other Iron Age sites, such as Castrolandín (MartínSeijo 2008) or Frijão (Martín-Seijo et al. 2015), it seems that the last fire in Nabás was lit and fuelled using several plant-based implements and items that remained inside the round-house. Evidence of planks is not common in Iron Age contexts and those found at Nabás provide information about wood-working: 1) Quercus deciduous and evergreen were selected as raw material for crafting planks; and 2) they were obtained by radial or tangential splitting of the trunk or branch. The hook-like piece looks like another wooden object found at Coto do Mosteiro 
(Carballiño, Ourense), which was also made of deciduous Quercus wood (MartínSeijo and Carrión 2012) and was interpreted as an agricultural implement, but a different use cannot be discounted. Finally, the cork could be interpreted as part of a container or it could even have been used for its insulation and water-proofing qualities in the roof, as fragments of cork have been also identified in SU12 and SU18. The use of cork as an insulation material for storage facilities has been noted at other Iron Age sites (e.g. Tereso et al. 2013b) and its use was ethnographically attested at the top of [on top of?] thatched roofs (Veiga de Oliveira et al. 1994).

In the case of Nabás, the identification of wood probably related to roof building and thatching material deepens our understanding of round-house construction during the Iron Age, increasing the information obtained previously from other sites, such as Penices (Figueiral 1995; Queiroga 2015) and Alto do Castro (Cobas and Parcero 2006; Martín-Seijo 2013). Most of the taxa identified at Nabás are coincident with those identified at the hut of Penices, such as deciduous and evergreen Quercus, Fabaceae, Alnus, Corylus, Rosaceae/Maloideae and cork (Figueiral 1995). In the case of Nabás, based on the percentages (Tables 2 and 3) and tree-ring curvature (Fig. 6), both deciduous and evergreen Quercus were probably used as structural timbers of the roof. The presence of twigs and fragments with strong tree-ring curvatures (Fig. 6) in Fabaceae, Corylus avellana and deciduous Quercus sp. would suggest that they formed part of a hurdle or perhaps represent the remains of the thatching material. This interpretation is also supported by the identification of Phragmites/Arundo associated with them - the first time this taxon has been identified in an Iron Age context of northwest Iberia. Phragmites sp. and Arundo sp. are perennial grasses of the Gramineae genera that grow in wetlands (López 2006), with the former widely used for thatching throughout Europe (Menéndez 2008) and it has been identified as associated with a roof structure affected by a fire event in southern France (Buxó et al. 1996). In the case of Nabás, the main thatching material was probably a mixture of Fabaceae branches and leaves and Phragmites/Arundo stems. The use of Fabaceae, including the genera Cytisus sp., Genista sp., Adenocarpus sp. and Ulex sp., as thatching material has been attested in ethnographic studies of Northwest Iberia (e.g. Veiga de Oliveira et al. 1994; Varela and Fernández 2004; Menéndez 2008). Although no evidence for the use of cereal straw and even weeds for 
thatching have been identified in this context, the absence of these plants, and even other parasitic plants that usually colonise this kind of thatched roof (Menéndez 2008), could be related to the sampling bias introduced by the recovery method.

Evidence of the use of other plants during the occupation stage of Nabás could be also traced by pollen analyses. The two uppermost pollen samples were coincident with the paved floor and could be associated with the house at the time of use (Fig. 10), their results being different to samples located below (ESM B). These differences could be related to the confined space created by the presence of the wall and the roof. This probably conditioned the pollen input inside the roundhouse so that it was probably anthropic and related to the introduction of plants inside the house and not atmospherically induced. For instance, the high values of Ericaceae pollen in these samples contrasting with the absence of its macroremains could suggest that the presence of this plant or its inflorescences could result from its use inside the house or near the entrance.

\section{Chaîne-opératoire of the crop processing}

Only two cultivated species were identified in the carpological assemblage: barley and foxtail millet. The absence of weeds in the carpological samples could be related to plucking the ears of foxtail millet by hand, thus avoiding the presence of weeds during processing (Moreno-Larrazabal et al. 2015). However, it cannot be discounted that this gap could be a bias introduced by the recovery method. Leaving aside this methodological issue, the low richness identified in the assemblage could be connected to the chaîne-opératoire stage of these seeds. They could be classified as belonging to the storage stage of the sequence, based on the outcomes of the ethnobotanical study developed by Moreno-Larrazabal et al. (2015) - a hypothesis supported by the preservation of aggregate carpological remains, consisting of seeds and other plant parts of Setaria italica, that appear to have been burnt inside an organic wrap or container. The presence of stem fragments and inflorescences in Nabás show that seeds were winnowed or rudely sieved, but no fine sieving was performed (cf. Moreno-Larrazabal et al. 2015). The ultimate use of these seeds is difficult to determine, but there are several possibilities which are paralleled in some ethnographic studies (i.e. MorenoLarrazabal et al. 2015): 1) short-term storage related to the processing of the crop 
(pounding or milling) within the domestic space for human consumption; 2) storage of seeds for use in the next planting season; and 3) storage for later consumption.

The short list of crops contrasts with the high taxonomic richness identified in other hillforts from this geographical area (e.g. Tereso et al. 2013 [a, b or both?]), where Hordeum vulgare is a widespread and well-known cereal (Tereso et al. 2013b, 2016) and Setaria italica assemblages imply an interesting starting point for disentangling farming scenarios of millet cultivation in northwest Iberia. Broomcorn (Panicum miliaceum) and foxtail millet have been recorded in archaeological contexts in Iberia dating from the mid-second to first millennium BC. During the Iron Age, foxtail millet was most common in the east and north of Iberia, whilst broomcorn millet predominated in the northwest. This geographical difference is more pronounced in the northwest, where Setaria italica has only been identified in a few Iron Age sites, whereas broomcorn millet has been recorded even in Bronze Age contexts (Tereso et al. 2016). Recently, foxtail millet assemblages have been found in contexts dating to the early first century AD in northwest Iberia (e.g. Tereso et al. 2013a). Although the biography of Setaria cultivation is complex and further analyses are needed, radiocarbon dates from Nabás (Table 1) and other hillforts (Teira 2019) suggest that Setaria italica was cultivated in this geographical area at least as early as the Iron Age.

\section{The end of the round-house lifecycle}

What was the cause of the high quantity of charcoal recovered inside the roundhouse of Nabás? The existence of a fire event could be supported by both archaeobotanical and archaeological data: (1) the presence and good preservation of carbonised crafted wood; (2) the size of the charcoal fragments; (3) the absence of fragments without rounded corners; and (4) the absence of intermediate deposits between those deposits with the highest quantity of charcoal and the collapsed wall. The carbonised remains identified inside the round-house were probably elements of the collapsed structure, including thatching materials, the wooden framework and wickerwork structures, different kind of crafted objects and grains. The collapse of the structure probably occurred during the fire or shortly afterwards. 
Alterations related to the combustion process were identified in all the stratigraphic units, but differences between them were observed. The presence of vitrification of the tissues is higher in SU12 than in the others, whilst radial cracks are present in higher percentages in charcoal recovered from SU17. These differences have been also attested in the carpological remains. Differences in the state of preservation of Setaria italica inflorescences between crusts and single grains could be related to irregular burning conditions (Walsh 2017). Evidence of woodborers and fungi was identified in all the stratigraphic units, but the percentage of charcoal affected by xylophagous insects reached $12 \%$ of the sample in SU18. The presence of hyphae filaments was higher in charcoal recovered from SU12. The presence of both wood-rotting fungi and wood-boring animals is related to their symbiosis, with fungal attack already in progress when the wood-borers arrived (Hickin 1963). Wood used for building settlements and houses is usually affected by fungi and xylophagous insects, such as coleoptera belonging to the Ptinidae, Cerambycidae and Bostrichidae families (Fohrer et al. 2017). The presence of decayed wood would also support the hypothesis of charcoal being related to the roofing and thatching structure and even to the presence of other kinds of wooden objects inside the round-house.

The hypothesis that the house was deliberately set on fire is based on multiple archaeological and archaeobotanical evidences. The scarcity of pottery and other objects inside the house when the fire started could be related to the deliberate removal of all household goods as part of a planned house abandonment. The burning of planks and a tool as the main firewood within the hearth is an unusual practice, which has not been documented in other Iron Age houses of the area. The presence of a cobble in the centre of the wood burnt in the hearth, as well as the presence of grains in this feature and its immediate surroundings, could be considered to be intentional deposits. Of special interest is the presence of the Setaria italica crust within the hearth, which could be indicative of burning grains inside an organic wrap or container - this act of burning grains intentionally has no practical purpose because it destroys it as a food source as well as the seed for the following harvest (Williams 2003).

The transformative power of fire was probably used in Nabás as a way of ending the lifecycle of this round-house, marking the abandonment of the entire settlement, as similar evidence of deliberate burning was recorded at other 
structures in this site. The houses were not occupied after this burning episode, which symbolizes the end of the occupation phase. In Nabás, at a given time and for an unknown reason the community that inhabited this site decided to undertake a planned abandonment and destruction of the settlement, whether by their own choice or forced by others. Though there are no references to this kind of behaviour in other Iron Age sites in northwest Iberia, an episode of intentionally destroying objects, including crafted wood, and food has been also identified in Frijão in a feasting context (Tereso and Silva 2014; Martín-Seijo et al. 2015), and similar abandonment practices have been proposed in Iron Age round-houses in other geographical areas (Williams 2003; Webley 2007).

\section{Conclusions}

Statistical analyses of the charcoal samples recovered at Nabás support the tandem approach of handpicked and bulk samples in contexts affected by fire events (ESM A). This strategy for recovery increases the possibilities of identifying wooden objects and minimises the overrepresentation of taxa as a result of the fragmentation of larger pieces of charcoal. Whilst differences between handpicked and bulk samples are only dependant on the number of fragments analysed per sample, when more than 99 fragments are analysed no differences are observed. The exhaustive description of taphonomic and dendrological attributes in each taxonomically identified charcoal fragment also provides useful information to interpret and reconstruct formation processes of the archaeobotanical assemblages and even to understand the processes that impacted upon the archaeological dwellings.

The archaeological and archaeobotanical data indicate that the round-house of Nabás was destroyed during a fire event that marked the end of its lifecycle and the occupation of the site in a planned act of abandonment and destruction. The distribution of charcoal and the short taxonomic list identified, as well as the taphonomical and dendrological attributes recorded, indicate that most of charcoal recovered belonged to building and thatching material. Deciduous and evergreen Quercus were the preferred taxa for making wooden planks and implements, and for building; other taxa related to roofing and thatching were Fabaceae, Corylus avellana, Alnus sp., Rosaceae/Maloideae, Betula sp., Salix/Populus, Frangula alnus and Phragmites/Arundo. The data provided by pollen and charcoal samples 
also indicate that wood gathering probably took place in the environs of the site, where small stands or some specimens of Castanea and Juglans were present in an indeterminate period prior to the construction of the round-house. The pollen identified in the occupation floor could provide evidence of the use of different plants, including trees, shrubs and herbaceous plants, during its period of use. Among the preserved taxa, Ericaceae seems to have had a relevant presence inside the structure not linked to firewood use. The Iron Age communities that inhabited Nabás developed a diversified exploitation of local resources that involved the exploitation of mixed oak forests with thermophilous taxa, scrublands and riverine forests and wetlands, and silvicultural practices such as coppicing. The identification of the storage of Setaria italica seeds inside the round-house and the radiocarbon dates obtained in Nabás and Castrolandín suggest its cultivation in northwest Iberia since at least as early as the Iron Age.

Acknowledgements María Martín-Seijo was funded by a Post-Doc Grant Plan I2C mod. $B$ with the project "MATERIAL-Materiality and Material Culture: Wood and Other Plant-based Materials in Archaeological Contexts" and Andrés Currás was funded by the Xunta de Galicia under the GAIN Postdoctoral Program. The excavation of Nabás, led by MMS in 2006, was funded by the Consellería de Cultura-Xunta de Galicia (2006-CP035). Charcoal and carpological analyses were undertaken at the Laboratory of the Study Group for the Prehistory of NW Iberia-Archaeology, Antiquity and Territory (GEPNAAT) and pollen analysis at the SERP-Universitat de Barcelona. The authors are grateful to Clíodhna Ní Lionáin for reviewing the English version of the text.

\section{References}

Almeida CAF, Soeiro T, Almeida CAB, Baptista AJ (1980) Escavações arqueológicas em Santo Estevão da Facha. Arquivo de Ponte de Lima 3:3-90

Alves F, Rieth E (2007) As pirogas 4 e 5 do rio Lima. Trabalhos do CNANS 21. Instituto Portugués de Arqueologia, Lisboa

Amigo J, Rodríguez-Guitián MA, Pradinho Honrado JJ, Alves P (2017) The Lowlands and Midlands of Northwestern Atlantic Iberia. In: Loidi J (ed) The Vegetation of the Iberian Peninsula. Springer, Berlin, pp 191-250. doi:10.1007/978-3-319-54784-8

Andersen ST (1979) Identification of wild grass and cereal pollen. Aarbog. Danmarks Geologiske Undersoegelse. Reitzels forlag, Copenhagen

Behre K-E (1981) The interpretation of anthropogenic indicators in pollen diagrams. Pollen et spores 23:225245 
Behre K-E (1986) Analysis of botanical macro-remains. In: van de Plassche O (ed) Sea-Level Research: a manual for the collection and evaluation of data. Springer, Dordrecht, pp 413-433

Blackford JJ, Innes JB (2006) Linking current environments and processes to fungal spore assemblages: surface NPM data from woodland environments. Rev Palaeobot Palynol 141:179-187. https://doi.org/10.1016/j.revpalbo.2006.03.010

Blanco-González A (2011) From huts to 'the house': the shift in perceiving home between the Bronze Age and the Early Iron Age in central Iberia (Spain). Oxford J Archaeol 30:393-410. https://doi.org/10.1111/j.1468-0092.2011.00373.x

Borcard D, Gillet F, Legendre P (2011) Numerical Ecology with R. Springer, New York Bottema S, Woldring H (1990) Anthropogenic indicators in the pollen record of the Eastern Mediterranean. In: Bottema S, Entjes-Nieborg G, van Zeist W (eds) Handbook of Man's Role in the Shaping of the Eastern Mediterranean Landscape. Balkema, Rotterdam, pp 231-264

Braadbaart F, Poole I (2008) Morphological, chemical and physical changes during charcoalification of wood and its relevance to archaeological contexts. J Archaeol Sci 35:2,434-2,445.

https://doi.org/10.1016/j.jas.2008.03.016

Brück J (1999) Houses, lifecycles and deposition on Middle Bronze Age settlements in southern England. Proc Prehist Soc 65:145-166. https://doi.org/10.1017/S0079497X00001973

Brück J (2006) Fragmentation, personhood and the social construction of technology in Middle and Late Bronze Age Britain. Cambridge Archaeol J 16:297-315. https://doi.org/10.1017/S0959774306000187

Buxó R, Chabal L, Roux JC (1996) Toiture et restes carbonisés d'une maison incendiée dans l'habitat de Lattes au IVe s. av. n. è. Lattara 9:373-398

Carballo LX (1990) Los castros de la cuenca media del río Ulla y sus relaciones con el medio físico. Trabajos de Prehistoria 47:161-199

Carballo LX (1996) Os castros galegos, espacio e arquitectura. Gallaecia 14-15:309-358

Carballo LX (2002) A Cultura Castrexa na Comarca de Deza. Seminario de Estudios de Deza, Lalín Carrión Y (2005) La vegetación mediterránea y atlántica de la península Ibérica: Nuevas secuencias antracológicas. Servicio de Investigación Prehistórica 104. Diputación Provincial de Valencia, Valencia

Chabal L (1997) Forêts et sociétés en Languedoc (Néolithique final, Antiquité tardive): l'anthracologie, méthode et paléoécologie. Éditions de la Maison des Sciences de l'Homme, Paris

Chrzazvez J, Théry-Parisot I, Fiorucci G, Terral J-F, Thibaut B (2014) Impact of post-depositional processes on charcoal fragmentation and archaeobotanical implications: experimental approach combining charcoal analysis and biomechanics. J Archaeol Sci 44:30-42. https://doi.org/10.1016/j.jas.2014.01.006

Cobas I, Parcero C (2006) Alto do Castro (Cuntis, Pontevedra). Síntesis de resultados y estudio de materiales, campaña 1993. TAPA 37. Instituto de Estudos Galegos Padre Sarmiento, Santiago de Compostela

Coles B, Coles J (1986) Sweet Track to Glastonbury: The Somerset Levels in Prehistory. Thames and Hudson, London

Coles JM, Heal SVE, Orme BJ (1978) The Use and Character of Wood in Prehistoric Britain and Ireland. Proc Prehist Soc 44:1-45 
Crone A, Barber J (1981) Analytical techniques for the investigation of non-artefactual wood from prehistoric and medieval sites. Proc Soc Antiq Scot 111:510-515

Costas J, Hidalgo JM, Sobral JM, Viñas R (1996) Raíces de Nigrán: dende os petroglifos ata o Arco Visigodo. Concello de Nigrán, Nigrán

Costas S, Sobrino CM, Alejo I, Pérez-Arlucea M (2009) Holocene evolution of a rock-bounded barrierlagoon system, Cíes Islands, northwest Iberia. Earth Surf Process Landf 34:1,575-1,586. https://doi.org/10.1002/esp.1849

Cugny C, Mazier F, Galop D (2010) Modern and fossil non-pollen palynomorphs from the Basque mountains (western Pyrenees, France): the use of coprophilous fungi to reconstruct pastoral activity. Veget Hist Archaeobot 19:391-408. https://doi.org/10.1007/s00334-010-0242-6

Desprat S, Sánchez-Goñi MF, Loutre M-F (2003) Revealing climatic variability of the last three millennia in northwestern Iberia using pollen influx data. Earth Planet Sci Lett 213:63-78. https://doi.org/10.1016/S0012821X(03)00292-9

Ejarque A, Julià R, Riera S, Palet JM, Orengo HA, Miras Y, Gascón C (2009) Tracing the history of highland human management in the eastern Pre-Pyrenees: an interdisciplinary palaeoenvironmental study at the Pradell fen, Spain. Holocene 19:1,241-1,255. https://doi.org/10.1177/0959683609345084

Fábregas-Valcarce R, Martínez-Cortizas A, Blanco Chao R, Chesworth W (2003) Environmental change and social dynamics in the second-third millennium BC in NW Iberia. J Archaeol Sci 30:859-871.

https://doi.org/10.1016/S0305-4403(02)00264-9

Faegri K, Iversen J (1989) Textbook of Pollen Analysis, 4th edn by Faegri K, Kaland PE, Krzywinski K (eds). Blackburn Press, Caldwell N.J.

Figueiral I (1995) Evidence from charcoal analysis for environmental change during the interval late Bronze Age to Roman, at the archaeological site of Castro de Penices, N.W. Portugal. Veget Hist Archaeobot 4:93100. https://doi.org/10.1007/BF00206917

Figueiral I (1996) Wood resources in north-west Portugal: their availability and use from the late Bronze Age to the Roman period. Veget Hist Archaeobot 5:121-129. https://doi.org/10.1007/BF00189442

Figueiral I, Bettencourt AMS (2004) Middle/Late Bronze Age plant communities and their exploitation in the Cávado Basin (NW Portugal) as shown by charcoal analysis: the significance and co-occurrence of Quercus (deciduous) - Fabaceae. Veget Hist Archaeobot 13:219-232. https://doi.org/10.1007/s00334-004-0040-0

Fohrer F, Toriti M, Durand A (2017) Analyse des vermoulures pour la détermination de quelques espèces d'insectes xylophages de la famille des Ptinidae (Coleoptera). Bull Soc Entomol Fr 122:133-142

Gale R, Cutler D (2000) Plants in Archaeology: Identification manual of vegetative plant materials used in Europe and the southern Mediterranean to c. 1500. Westbury and Royal Botanic Gardens, Kew

García-Rollán M (1971) Memoria de la excavación arqueológica de Castromao (Caeliobriga). Archivo Español de Arqueología 44:175-211

Garrow D (2012) Odd deposits and average practice: a critical history of the concept of structured deposition. Archaeological Dialogues 19:85-115. http://dx.doi.org/10.1017/S1380203812000141

Gerritsen F (1999) To build and to abandon: The Cultural Biography of Late Prehistoric Houses and Farmsteads in the Southern Netherlands. Archaeological Dialogues 6:78-97.

https://doi.org/10.1017/S1380203800001410 
Gerritsen F (2007) Relocating the house. Social transformations in late prehistoric Northern Europe. In: Beck RA (ed) The Durable House. House Society Models in Archaeology. Center for Archaeological Investigations, Southern Illinois University, Carbondale, pp 154-174

Gerritsen F (2008) Domestic times: houses and temporalities in late prehistoric Europe. In: Jones A (ed) Prehistoric Europe. Theory and Practice. Wiley-Blackwell, Hoboken N.J., pp 143-161

Gómez-Orellana L, Ramil-Rego P, Aira Rodríguez MJ (1996) Cronología y dinámica de los humedales y lagunas existentes en las depresiones sedimentarias de Galicia. In: Ruiz Zapata MB (ed) Estudios Palinológicos. Universidad de Alcalá de Henares, Alcalá de Henares, pp 63-67

Greenacre M, Primicerio R (2013) Multivariate analysis of ecological data. Fundación BBVA, Madrid Grimm EC (1987) CONISS: a FORTRAN 77 program for stratigraphically constrained cluster analysis by the method of incremental sum of squares. Comput Geosci 13:13-35. https://doi.org/10.1016/0098-

3004(87)90022-7

Harding DW (2009) The Iron Age round-house: later prehistoric building in Britain and beyond. Oxford University Press, Oxford

Hather JG (2000) The Identification of the Northern European Woods: A guide for archaeologists and conservators. Archetype Publications, London

Hickin NE (1963) The Insect Factor in Wood Decay: An Account of Wood-boring Insects with Particular Reference to Timber Indoors. Hutchinson \& Co. Ltd., London

Jacomet S (2006) Identification of Cereal Remains from Archaeological Sites, 2nd edn. Archaeobotany Lab, IPAS, Basel University, Basel

Jordá-Pardo JF, Rey Castiñeira J, Picón Platas I, Abad Vidal E, Marín Suárez C (2009) Radiocarbon and chronology of the Iron Age hillforts of Northwestern Iberia. In: Karl R, Leskovar J (eds) Interpretierte Eisenzeiten. Fallstudien, Methoden, Theorie. Tagungsbeiträge der 3 Linzer Gespräche zur interpretativen Eisenzeitarchäologie. Studien zur Kulturgeschichte von Oberösterreich. Oberösterreichisches Landesmuseum, Linz, pp 81-98

Lancelotti C, Madella M, Ajithprasad P, Petrie CA (2010) Temperature, compression and fragmentation: an experimental analysis to assess the impact of taphonomic processes on charcoal preservation. Archaeol Anthropol Sci 2:307-320. https://doi.org/10.1007/s12520-010-0046-8

López G (2006) Los árboles y arbustos de la Península Ibérica e Islas Baleares. Ed. Mundi Prensa, Madrid López-Cuevillas F, Lorenzo-Fernández X (1986) Castro de Cameixa: Campañas 1944-46. Arqueoloxía/Memorias. Xunta de Galicia, Santiago de Compostela

Marguerie D, Hunot JY (2007) Charcoal analysis and dendrology: data from archaeological sites in Northwestern France. J Archaeol Sci 34:1,417-1,433. https://doi.org/10.1016/j.jas.2006.10.032

Martín-Seijo M (2008) Os combustibles e as manufacturas en madeira durante a Idade do Ferro: estudo antracolóxico do xacemento de Castrolandín (Cuntis, Pontevedra). Estudos do Quaternário 5:87-98

Martín-Seijo M (2013) A xestión do bosque e do monte dende a Idade do Ferro a época romana no noroeste da península Ibérica: consumo de combustibles e produción de manufacturas en madeira. PhD Thesis, University of Santiago de Compostela, Santiago de Compostela

Martín-Seijo M, Carballo LX (2010) Le travail du bois et les pratiques d'élagage à l'Âge du fer: le site de Castrovite (Galice, Espagne). In: Delhon C, Théry-Parisot I, Thiébault S (dir) Des Hommes et des Plantes. 
Exploitation du Milieu et des ressources végétales de la Préhistoire à nos jours. Éditions APDCA, Antibes, pp 253-266

Martín-Seijo M, Carrión Y (2012) Shaping Wood: Woodworking during the Iron Age and Roman period in the northwest of the Iberian Peninsula. In: Badal E, Carrión J, Marcías M, Ntinou M (coord) Wood and Charcoal. Evidence for Human and Natural History. Sagvntvm Extra-13. Universitat de Valéncia, Valencia, pp 135-144

Martín-Seijo M, Piqué R (2013) New data about wood use in the Northwest of the Iberian Peninsula. In: Damblon F (ed) Proceedings of the Fourth International Meeting of Anthracology, Brussels, 8-13 September 2008, Royal Belgian Institute of Natural Sciences. BAR International Series 2486. Archaeopress, Oxford, pp 143-154

Martín-Seijo M, Blanco-González A, Teira-Brión A, Rodríguez Rellán C, Bettencourt AMS, Rodríguez Sáiz ER, Comendador Rey B (2017) Disentangling the life-cycles of Bronze Age pits: A multi-stranded approach, integrating ceramic refitting, archaeobotany and taphonomy. J Archaeol Sci: Rep 12:528-542. https://doi.org/10.1016/j.jasrep.2017.02.024

Martín-Seijo M, Silva VMF, Bettencourt AMS (2015) Carbonised wooden objects and wood charcoal from an Iron Age feasting context in North-western Iberia: The case study of Frijão (Braga, Portugal). J Archaeol Sci: Rep 2:538-550. https://doi.org/10.1016/j.jasrep.2015.05.005

Martín-Seijo M, Tereso JP, Bettencourt AMS, Sampaio HA, Abad E, Vidal L (2017a) Socio-ecology of Early and Middle Bronze Age communities in the northwest Atlantic region of Iberia: Wood resources procurement and forest management. Quat Int 437:90-101. https://doi.org/10.1016/j.quaint.2015.08.026

Martín-Seijo M, Tereso JP, Vaz FC, Gaspar R, Rodríguez Rellan C (2017b) Early-Middle Bronze Age communities and wood resources management in northeast Portugal: The Sabor valley. Quat Int 458:28-43. https://doi.org/10.1016/j.quaint.2017.04.032

Martins M (1990) O Povoamento proto-histórico e a romanização da bacia do curso médio do Cávado.

Cadernos de Arqueologia, Monografias 5. Unidade de Arqueologia da Universidade do Minho, Braga

McParland LC, Collinson ME, Scott AC, Campbell G, Veal R (2010) Is vitrification in charcoal a result of high temperature burning of wood? J Archaeol Sci 37:2,679-2,687. https://doi.org/10.1016/j.jas.2010.06.006

Ménendez C-O (2008) Teitos. Cubiertas vegetales de Europa Occidental: de Asturias a Islandia. Colegio Oficial de Aparejadores y Arquitectos Técnicos del Principado de Asturias, Oviedo

Mora-González A, Teira-Brión A, Granados-Torres A, Contreras-Cortés F, Delgado-Huertas A (2019)

Agricultural production in the 1st millennium BCE in Northwest Iberia: results of carbon isotope analysis.

Archaeol Anthrop Sci 11:2,897-2,909. https://doi.org/10.1007/s12520-018-0721-8

Moreno-Larrazabal A, Teira-Brión A, Sopelana-Salcedo I, Arranz-Otaegui A, Zapata L (2015) Ethnobotany of millet cultivation in the north of the Iberian Peninsula. Veget Hist Archaeobot 24:541-554. https://doi.org/10.1007/s00334-015-0518-y

Moskal del Hoyo M, Wachowiak M, Blanchette RA (2010) Preservation of fungi in archaeological charcoal. J Archaeol Sci 37:2,106-2,116. https://doi.org/10.1016/j.jas.2010.02.007

Muñoz Sobrino C, García-Gil S, Diez JB, Iglesias J (2007) Palynological characterization of gassy sediments in the inner part of Ría de Vigo (NW Spain). New chronological and environmental data. Geo-Marine Letters 27:289-302. https://doi.org/10.1007/s00367-007-0078-y 
Muñoz Sobrino C, García-Gil S, Iglesias J, Martínez Carreño N, Ferreiro da Costa J, Díaz Varela RA, Judd A (2012) Environmental change in the Ría de Vigo, NW Iberia, since the mid-Holocene: new palaeoecological and seismic evidence. Boreas 41:578-601. https://doi.org/10.1111/j.1502-3885.2012.00255.x

Muñoz Sobrino C, García-Moreiras I, Castro Y et al (2014) Climate and anthropogenic factors influencing an estuarine ecosystem from NW Iberia: new high-resolution multiproxy analyses from San Simon Bay (Ría de Vigo). Quat Sci Rev 93:11-33. https://doi.org/10.1016/j.quascirev.2014.03.021

Muñoz Sobrino C, García-Moreiras I, Martínez Carreño N et al S (2016) Reconstruction of the environmental history of a coastal insular system using shallow marine records: the last three millennia of the Cíes Islands (Ría de Vigo, NW Iberia). Boreas 45:729-753. https://doi.org/10.1111/bor.12178

Neef R, Cappers RTJ, Bekker RM (2012) Digital Atlas of Economic Plants in Archaeology. Barkhuis, Eelde and Groningen University Library, Groningen

Oksanen J, Guillaume Blanchet F, Friendly M et al (2018) vegan: Community Ecology Package. R package version 2.5-2. https://CRAN.R-project.org/package=vegan. Accessed 28 October 2018

Orero L (1988) Castro de Coto do Mosteiro: Campañas 1984/5. Xunta de Galicia, Santiago de Compostela Parcero C (2003) Looking forward in anger: social and political transformations in the Iron Age of the northwestern Iberian Peninsula. Eur J Archaeol 6:267-299. https://doi.org/10.1179/eja.2003.6.3.267

Parcero C (2006) Los paisajes agrarios castreños: Modelos de construcción del espacio agrario a lo largo de la Edad del Hierro del noroeste. Arqueología Espacial 26:57-85

Parcero C, Cobas I (2004) Iron Age archaeology of the northwest Iberian Peninsula. e-Keltoi: J Interdiscip Celtic Stud 6:1-72

Pillonel D (2007) Technologie et usage du bois au Bronze final. Hauterive-Champréveyres 14, Archéologie neuchâteloise 37. Office et musée cantonal d'archéologie, Neuchâtel

Queiroga F (2015) As cabanas do Castro de Penices, e a evolução da arquitectura doméstica dos castros. Portvgalia, Nova Série 36:263-276

R Core Team (2018) R: A language and environment for statistical computing. R Foundation for Statistical Computing, Vienna, Austria. URL https://www.R-project.org/. Accessed 28 October 2018

Reille M (1992-1998) Pollen et Spores d'Europe et d'Afrique du Nord. Laboratoire de Botanique historique et Palynologie, Marseille

Reimer PJ, Bard E, Bayliss A et al (2013) IntCal13 and Marine13 Radiocarbon Age Calibration Curves 050,000 Years cal BP. Radiocarbon 55:1,869-1,887

Rey J (1992) Yacimientos castreños de la Vertiente Atlántica: análisis de la cerámica indígena. PhD Thesis, University of Santiago de Compostela, Santiago de Compostela

Rey J, Abad E, Calo N et al (2009) Metodoloxía e criterios para o estudo dos materiais arqueolóxicos: o proxecto do castro da Punta do Muiño. Gallaecia 28:213-232

Rey J, Martín-Seijo M, Teira A et al (2011) CastroBYTE: un modelo para a xestión da información arqueolóxica. Gallaecia 30:63-102

Rodríguez-Ariza MO (1993) Los procesos de formación y transformación del registro arqueológico en los estudios antracológicos, In: Burillo F (ed) Procesos postdeposicionales. Arqueología Espacial 16-17. Seminario de Arqueología y Etnología Turolense, Colegio Universitario, Teruel, pp 371-390 
Rodríguez-Sáiz E (2010) Escavación arqueolóxica en área e control arqueolóxico para a construcción dun centro residencial en Castro de Navás, Priegue, Nigrán (Pontevedra). Unpublished Technical Report

Romero A (1976) El hábitat castreño. Colegio de Arquitectos de Galicia, Santiago de Compostela

Sánchez-Polo A, Blanco-González A (2014) Death, Relics, and the Demise of Huts: Patterns of Planned

Abandonment in Middle BA Central Iberia. Eur J Archaeol 17:4-26.

https://doi.org/10.1179/1461957113Y.0000000048

Schiffer MB (1987) Formation Processes of the Archaeological Record. University of Utah Press, Salt Lake City

Schweingruber FH (1990) Anatomy of European Woods: An atlas for the identification of European trees, shrubs and dwarf shrubs. Haupt, Stuttgart

Schweingruber FH (2007) Wood structure and environment. Springer, Berlin, Heidelberg

Schweingruber FH, Börner A, Schulze ED (2008) Atlas of Woody Plant Stems: Evolution, Structure and Environmental Modifications. Springer, Berlin, Heidelberg

Seabra L, Tereso JP, Bettencourt AMS, Dinis A (2018) Crop diversity and storage structures in the settlement of Crastoeiro (Northwest Iberia): new approaches. Trabajos de Prehistoria 75:361-378

Shackley M (1985 [1981 in text?]) Using Environmental Archaeology. British Library, London

Silva ACF (1986) A cultura castreja no Noroeste de Portugal. Museu Arqueologico da Citánia de Sanfins, Paços de Ferreira

Sigüenza JM (1998) O castro de Navás en Priegue. Pontenova 3:41-44

Skibo JM, Schiffer MB (2008) People and Things: a Behavioural Approach to Material Culture. Springer, Berlin, Heidelberg

Teira A (2010) Tierra, metal y semillas. Consideraciones de la agricultura de la Edad del Hierro en Galicia. In: Bettencourt AMS, Alves MIC, Monteiro-Rodrigues S (eds) Variações Paleoambientais e Evolução Antrópica no Quaternário do Ocidente Peninsular. Associação Portuguesa para o Estudo do Quaternário (APEQ), Braga, pp 133-148

Teira A (2019) Cambio e resiliencia na agricultura e xestión de recursos vexetais no NW da Península Ibérica (1000 a.n.e.-400 d.n.e.). PhD Thesis, Universidade de Santiago de Compostela, Santiago de Compostela

Tereso JP (2012) Environmenttal change, agricultural development and social trends in NW Iberia from the Late Prehistory to the Late Antiquity. PhD, Universidade do Porto, Porto

Tereso JP, Silva VMF (2014) Fruits and seeds from an Iron Age ritual of commensality in Frijão (Braga, NW Portugal). Estudos do Quaternário/Quat Stud 11:67-72

Tereso JP, Bettencourt AMS, Ramil Rego P, Teira Brión A, López Dóriga I, Lima A, Almeida R (2016) Agriculture in NW Iberia during the Bronze Age: a review of archaeobotanical data. J Archaeol Sci: Rep 10:44-58. https://doi.org/10.1016/j.jasrep.2016.07.011

Tereso JP, Ramil-Rego P, Almeida-da-Silva R (2013a) Roman agriculture in the conventus Bracaraugustanus (NW Iberia). J Archaeol Sci 40:2,848-2,858. https://doi.org/10.1016/j.jas.2013.01.006 Tereso JP, Ramil-Rego P, Álvarez Y, López L, Almeida-da-Silva R (2013b) Massive storage in As Laias/O Castelo (Ourense, NW Spain) from the Late Bronze Age/Iron Age transition to the Roman period: a palaeoethnobotanical approach. J Archaeol Sci 40:3,865-3,877. https://doi.org/10.1016/j.jas.2013.05.007 
Théry-Parisot I (2001) Économie des combustibles au Paléolithique: Expérimentation, taphonomie, anthracologie. CNRS, Paris

Théry-Parisot I, Henry A (2012) Seasoned or green? Radial cracks analysis as a method for identifying the use of green wood as fuel in archaeological charcoal. J Archaeol Sci 39:381-388.

https://doi.org/10.1016/j.jas.2011.09.024

Théry-Parisot I, Chabal L, Chrzavzez J (2010) Anthracology and taphonomy, from wood gathering to charcoal analysis. A review of the taphonomic processes modifying charcoal assemblages, in archaeological contexts. Palaeogeogr Paleoclimatol Palaeoecol 291:142-153. https://doi.org/10.1016/j.palaeo.2009.09.016

Tringham R (2005) Weaving house life and death into places: a blueprint for a hypermedia narrative. In: Bailey D, Whittle A, Cummings V (eds) (Un)settling the Neolithic. Oxbow, Oxford, pp 98-111

Tringham R (2013) Destruction of Places by Fire: Domicide or Domithanasia. In: Driessen J (ed)

Destruction: archaeological, philological and historical perspectives. Presses universitaires de Louvain,

Louvain-laNeuve, pp 85-103

Van Geel B (2001) Non-pollen palynomorphs. In: Smol JP, Birks HJB, Last WM (eds) Tracking

Environmental Change Using Lake Sediments, Vol 3: Terrestrial, Algal and Silicaceaous Indicators. Kluwer Academic Publishers, Dordrecht, pp 99-119

Van Geel B, Aptroot A (2006) Fossil ascomycetes in Quaternary deposits. Nova Hedwigia 82:313-329. https://doi.org/10.1127/0029-5035/2006/0082-0313

Varela CX, Fernández FX (2004) As cubertas vexetais no noroeste peninsular. Raigame 20:20-53

Vaz FC, Tereso JP, Martín-Seijo M, Pereira S, Gaspar R, Seabra L, Sastre-Blanco J (2017) Iron Age ovens and hearths from the hilltop of Quinta de Crestelos, Sabor Valley (NE Portugal): An archaeobotanical approach on typology, functionality and firewood use. Quat Int 458:75-93.

https://doi.org/10.1016/j.quaint.2017.02.028

Veiga de Oliveira E, Galhano F, Pereira B (1994) Construções Primitivas em Portugal. Publicações Dom Quixote, Lisboa

Vermeeren CE (2001) Wood and Charcoal. In: Sidebothan S, Wendrich WZ (eds) Report of the 1998 Excavations at Berenike and the Survey of Egyptian Eastern Desert including Excavations at Wadi Kalalat. Research School of Asian, African, and Amerindian Studies (CNWS), Leiden, pp 311-342

Walsh R (2017) Experiments on the effects of charring on Setaria italica (foxtail millet). Veget Hist Archaeobot 26:447-453. https://doi.org/10.1007/s00334-016-0600-0

Webley L (2007) Using and abandoning roundhouses: a reinterpretation of the evidence from Late Bronze Age-Early Iron Age southern England. Oxford J Archaeol 26:127-144. https://doi.org/10.1111/j.14680092.2007.00277.x

Williams M (2003) Growing metaphors: the agricultural cycle as metaphor in the later prehistoric period of Britain and North-Western Europe. J Soc Archaeol 3:223-255.

https://doi.org/10.1177/1469605303003002005 


\section{Figure legends}

Fig. 1 Location of Nabás in northwest Iberia and other sites cited in the text: 1) Castrovite, 2) Neixón Grande, 3) Castrolandín, 4) Alto do Castro, 5) Castrelín, 6) Coto do Mosteiro, 7) As Laias, 8) Frijão, 9) As Ermidas and 10) Penices

Fig. 2 Samples: a) Intra-scale [Plan of round-house showing?] distribution of bulk and handpicked samples; b) Pollen column sample in the sedimentary profile of Structure 01 and c) Cross section of the round-house, with the indication of the SU cited in the text and the location of the pollen sample

Fig. 3 Cross sections of Alnus sp. (a, b), Corylus avellana (c, d), Ulmus sp. (e, f) and Phragmites/Arundo $(\mathrm{g}, \mathrm{h})$

Fig. 4 Alterations identified: (a) narrow rings in deciduous Quercus sp.; (b) scar in evergreen Quercus sp.; (c) wood-borer gallery and (d) radial cracks in Fabaceae

Fig. 5 Percentages of alterations related to the combustion process, comparison between SU12, SU18 and SU17

Fig. 6 Tree-ring curvature: W: weak; W-M: weak-moderate; M: moderate; M-S: moderate-strong; $S$ : strong; I: indeterminate

Fig. 7 Size of charcoal fragments in SU12 (B: bulk samples, H: handpicked samples)

Fig. 8 a) Drawing of the woodcrafts [wooden artefacts?] recovered within the hearth during the excavation process of this feature, in the centre of the feature coloured in grey a rubified cobble and clay blocks in orange; b and c) photographs of the woodcrafts [wooden artefacts?] during different stages of the excavation process

Fig. 9 Setaria italica seed (a), aggregated (b), vegetal structure (c) and stem (d)

Fig. 10 Percentage pollen diagram, at the left it is indicated the code of the samples (author: Andrés Currás)

Fig. 11 Percentage presence of taxa across the different samples analysed in this paper

Table $1{ }^{14} \mathrm{C}$ dates calibrated using Oxcal 4.2 (curve IntCal 13) (Reimer et al. 2013)

Table 2 Charcoal identification of water sieved samples (S: sub-sampled)

Table 3 Charcoal identification of handpicked samples (C: complete; S: sub-sampled)

Table 4 Plant part morphologically identified (TW: twig, ST: stem; KN: knot, BA: bark)

Table 5 Complete diameters of twigs and stems

Table 6 Description of carbonised woodcrafts [wooden artefacts?]

Table 7 Carpological identification of samples recovered by WS: water sieving, WO: wash-over sieving and HP: handpicking 


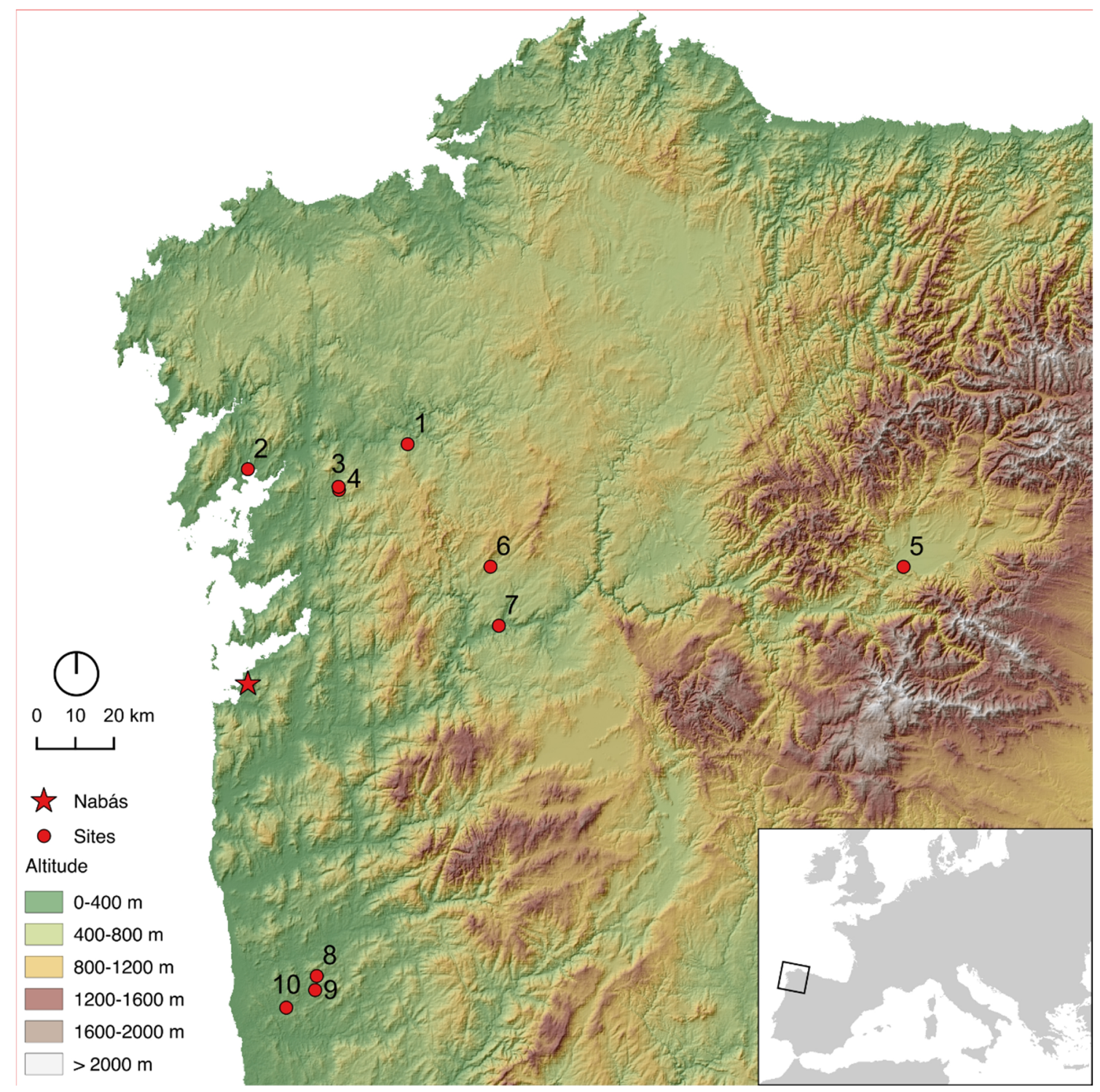

Fig. 1 Location of Nabás in northwest Iberia and other sites cited in the text: 1) Castrovite, 2) Neixón Grande, 3) Castrolandín, 4) Alto do Castro, 5) Castrelín, 6) Coto do Mosteiro, 7) As Laias, 8) Frijão, 9) As Ermidas and 10) Penices. 

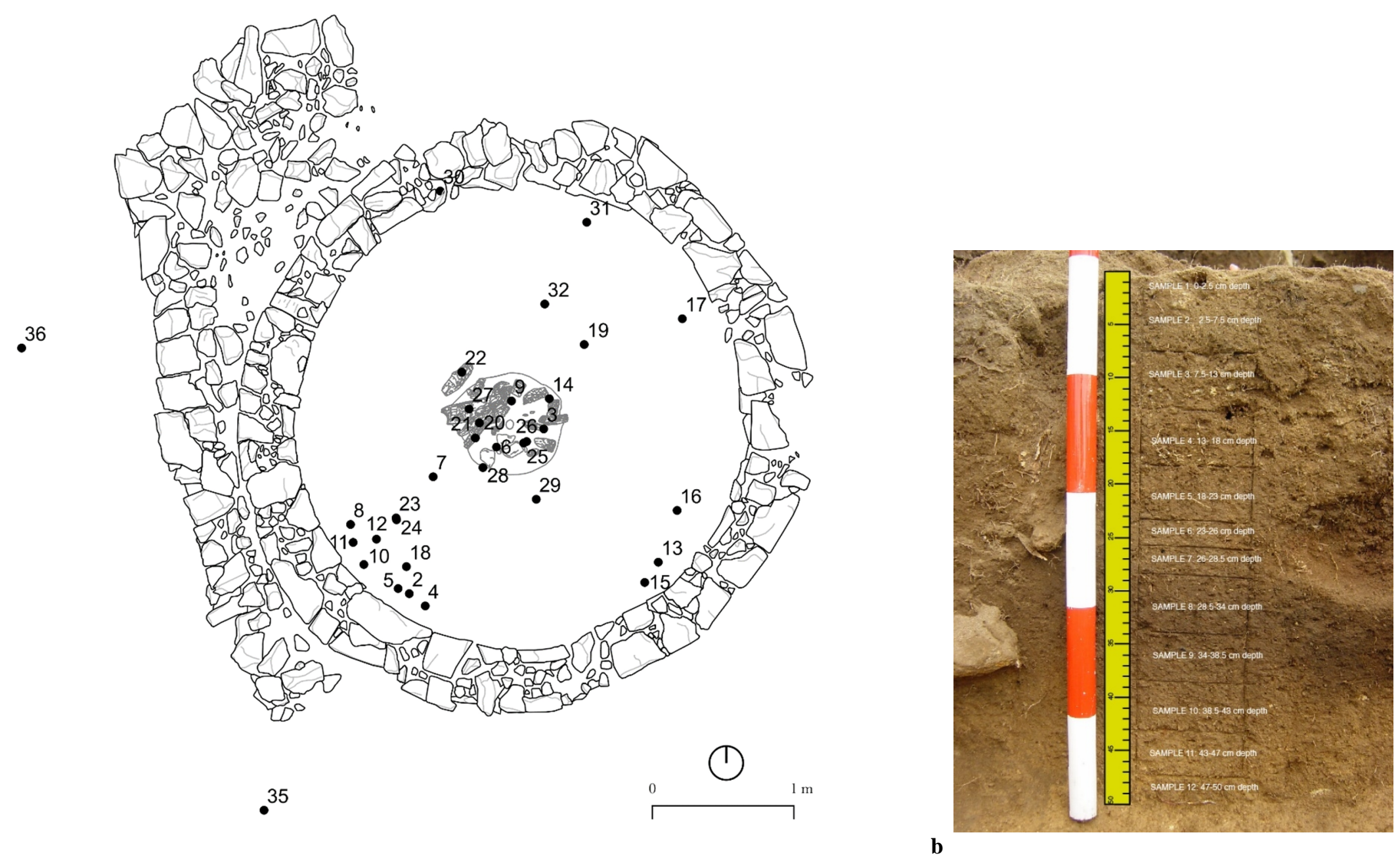

a 


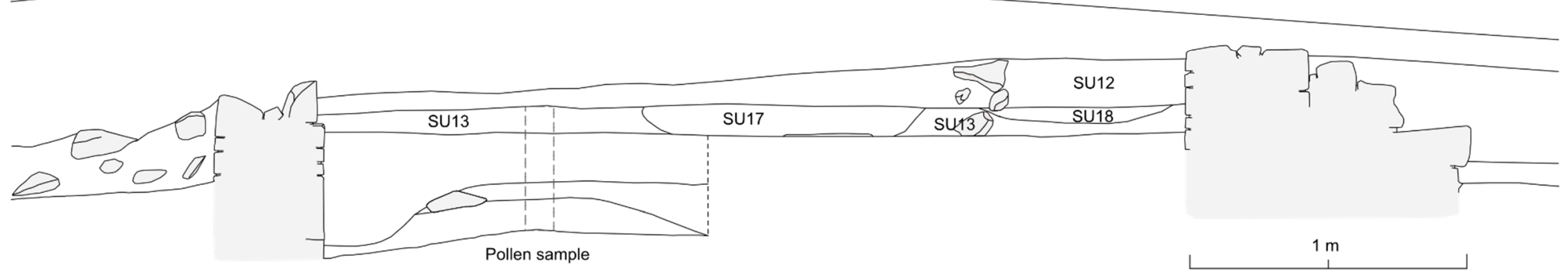

Fig. 2 Samples: a) Intra-scale distribution of bulk and handpicked samples, b) pollen column sample in the sedimentary profile of Structure 01 and c) cross section of the roundhouse, with the indication of the SU cited in the text and the location of the pollen sample. 

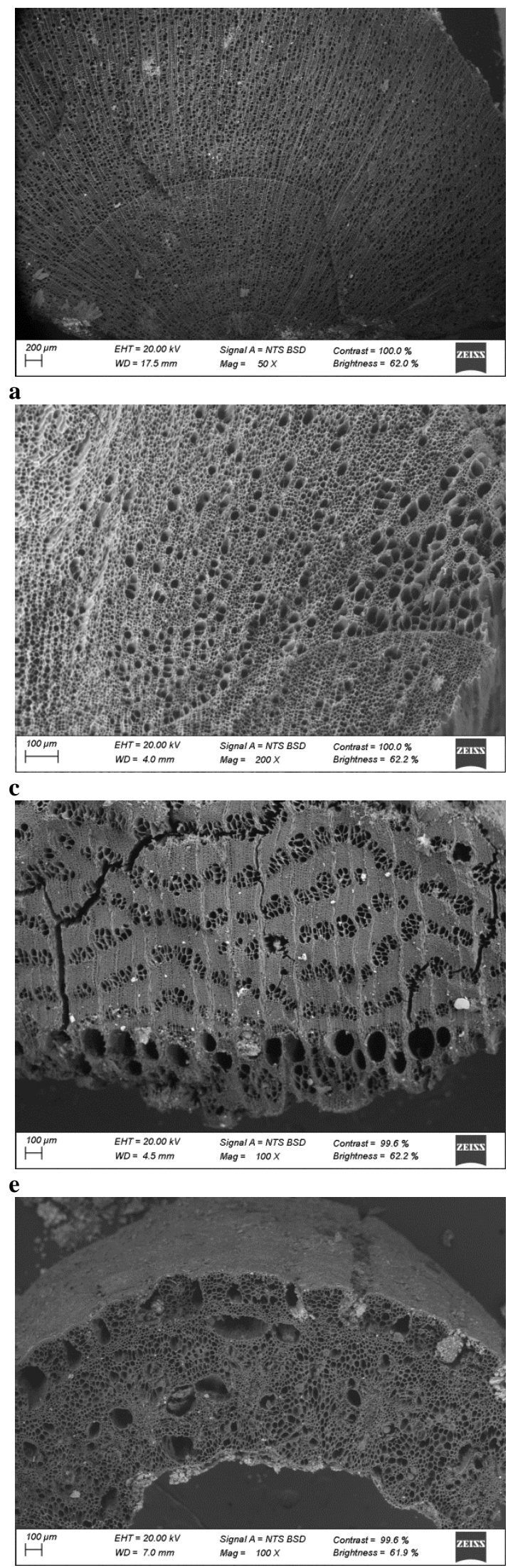

g
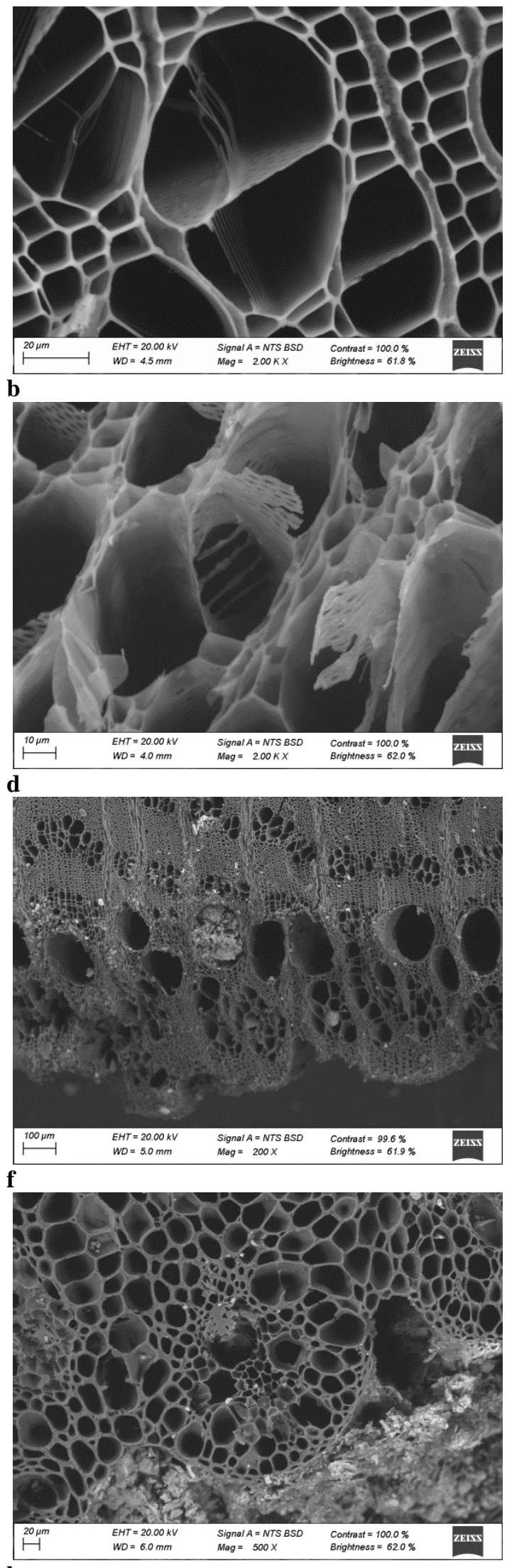

h

Fig. 3 Cross sections of Alnus sp. (a, b), Corylus avellana (c, d), Ulmus sp. (e, f) and Phragmites/Arundo $(\mathrm{g}, \mathrm{h})$. 


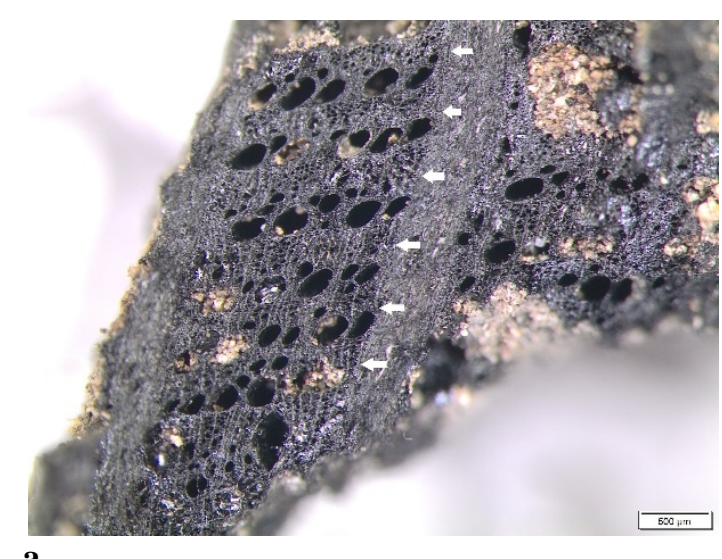

a
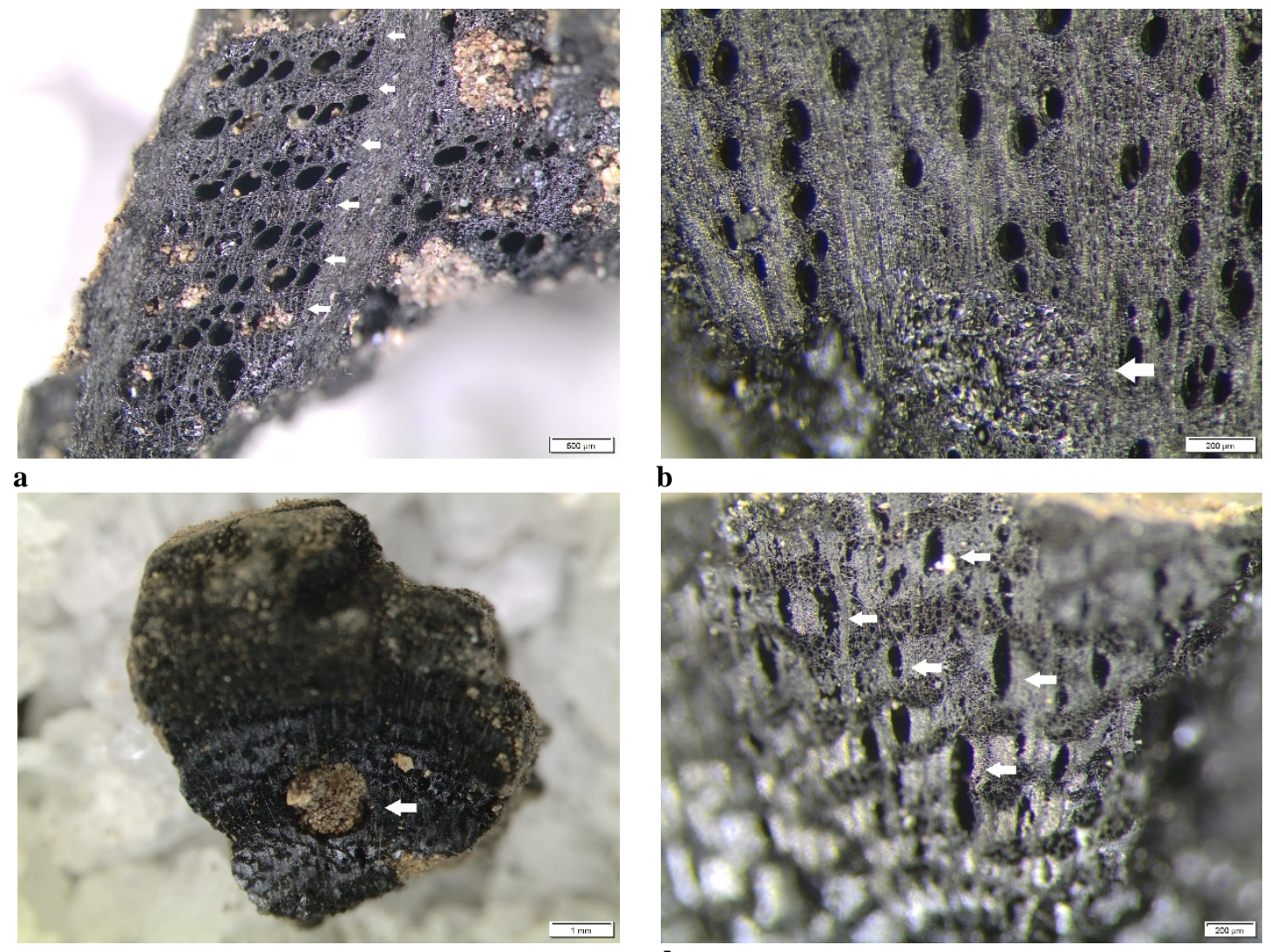

b

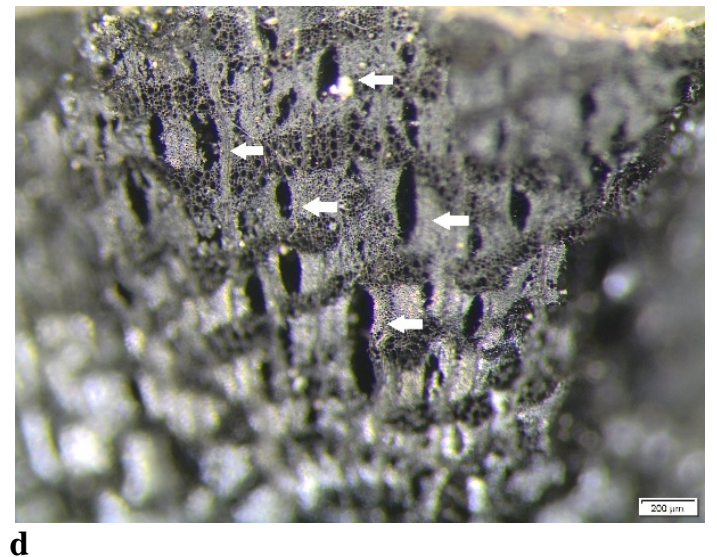

Fig. 4 Alterations identified: narrow rings in Quercus sp. deciduous (a), scar in Quercus sp. evergreen (b), wood-borer gallery (c) and radial cracks (d) in Fabaceae. 
30

25

20

15

10

0

SU18

30

25

20

15

10

5

0

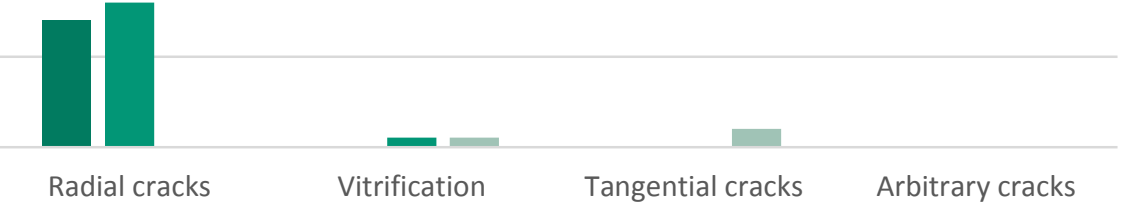

SU17

30

25

20

15

10

0

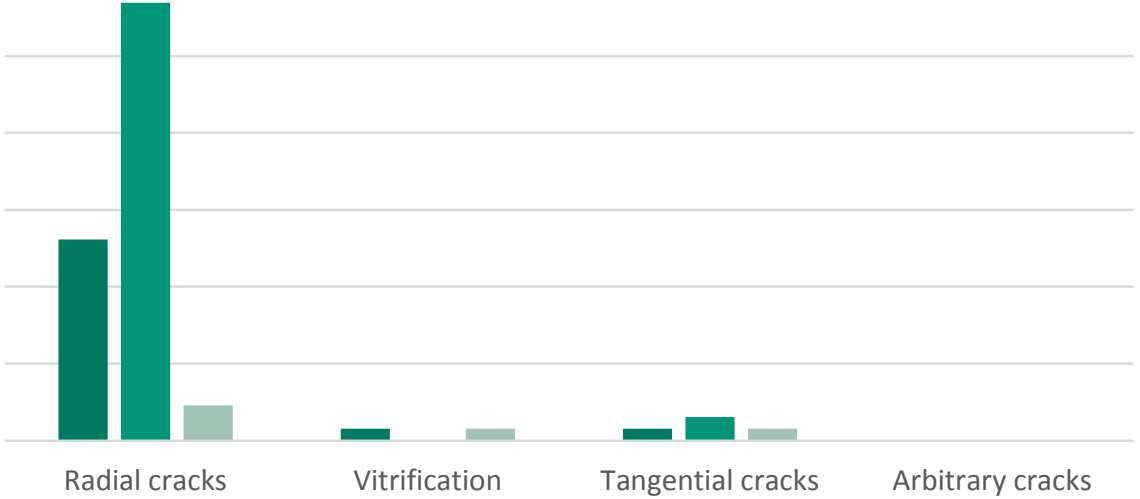

- Fabaceae

Quercus sp. deciduous

Others

Fig. 5 Percentages of alterations related to the combustion process, comparison between SU12, SU18 and SU17. 


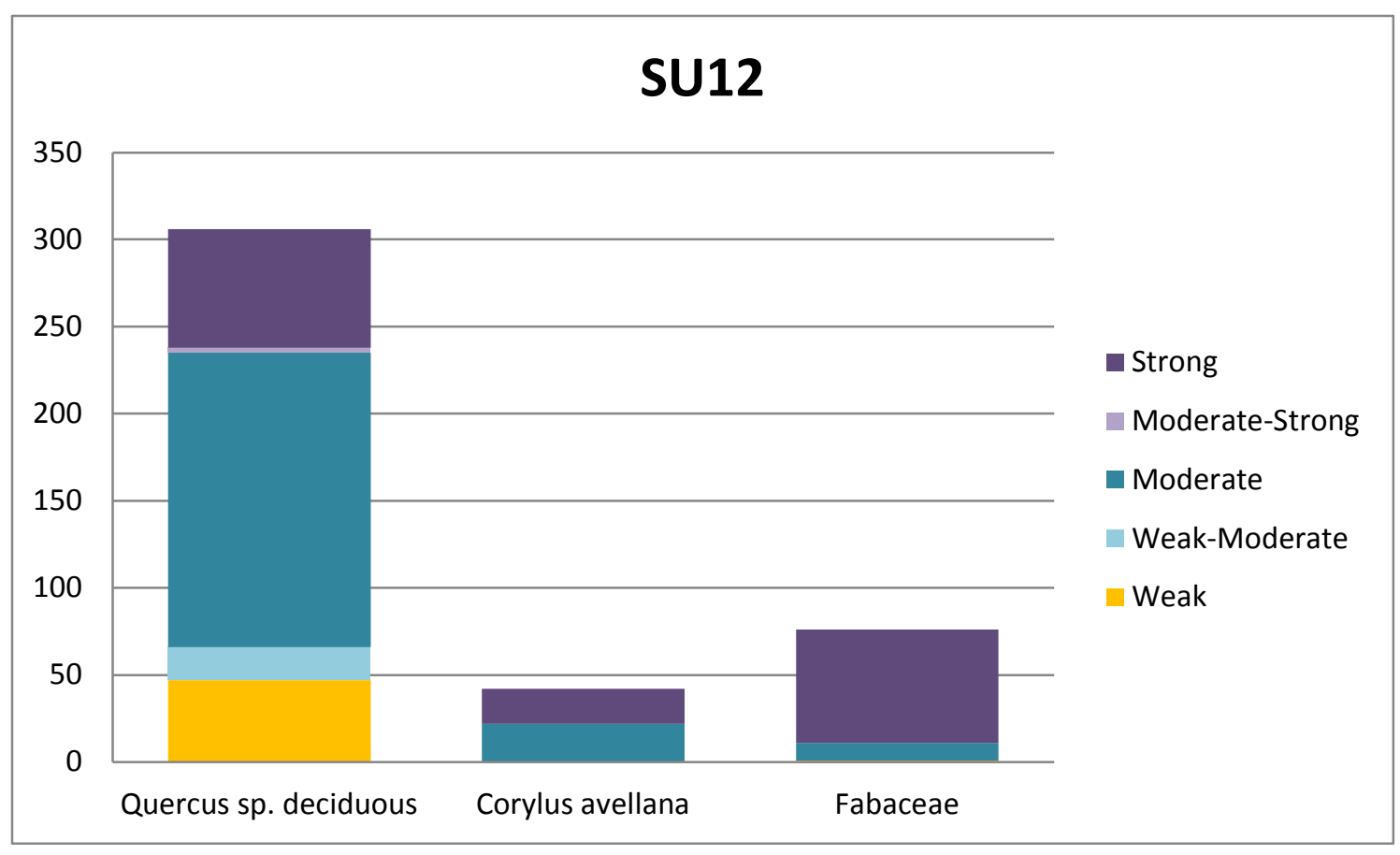

Fig. 6 Tree-ring curvature: W: weak; W-M: weak-moderate; M: moderate; M-S: moderate-strong; S: strong; I: indeterminate. 
SU12

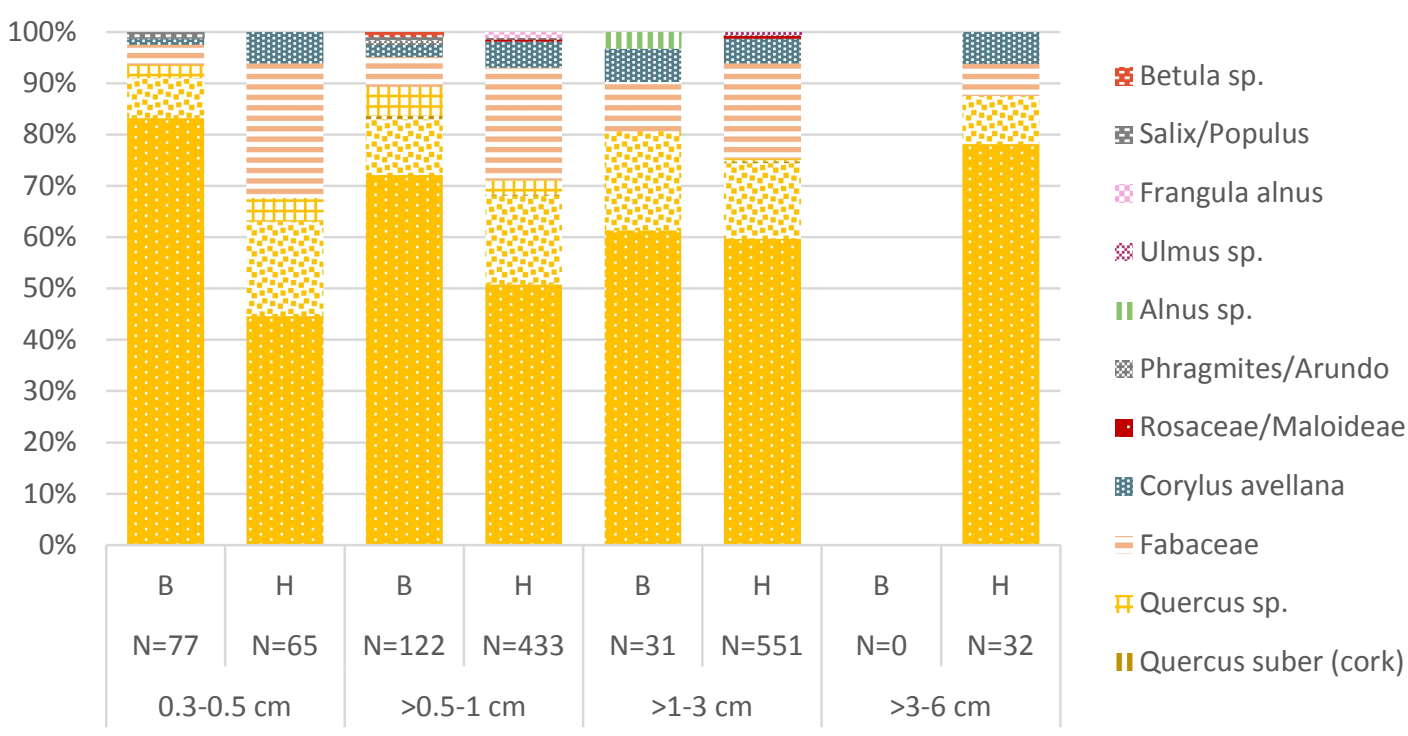

Fig. 7 Size of charcoal fragments in SU12 (B: bulk samples, H: handpicked samples). 


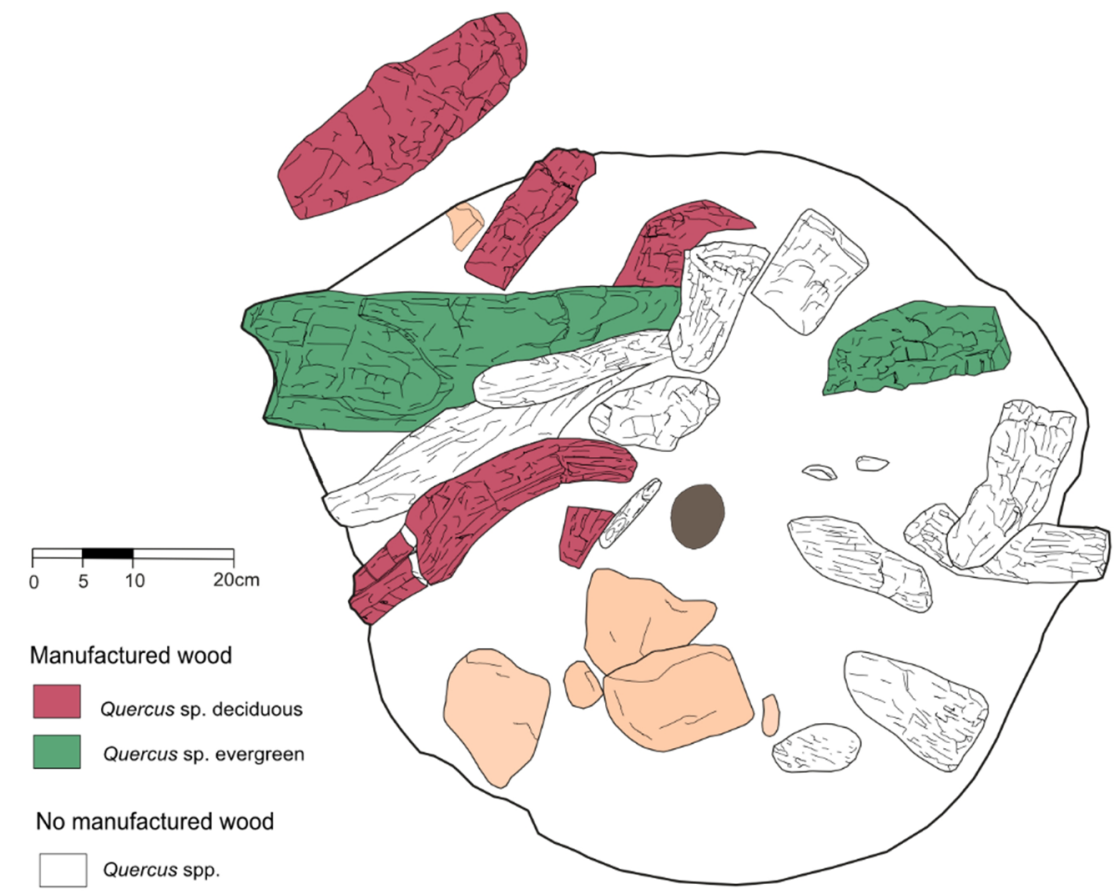

a

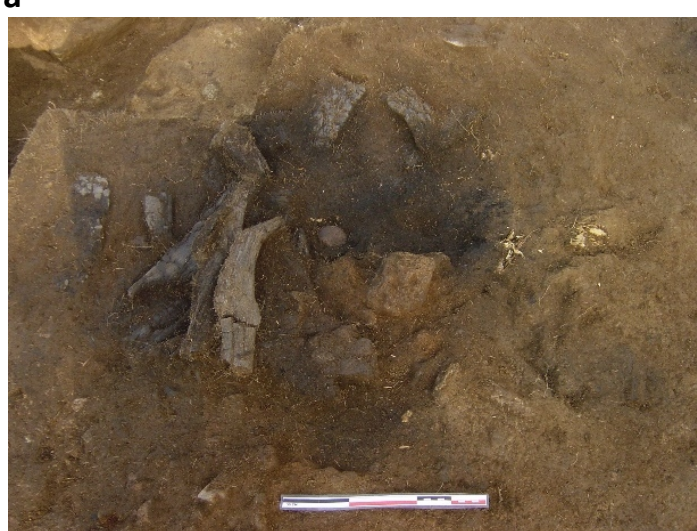

b

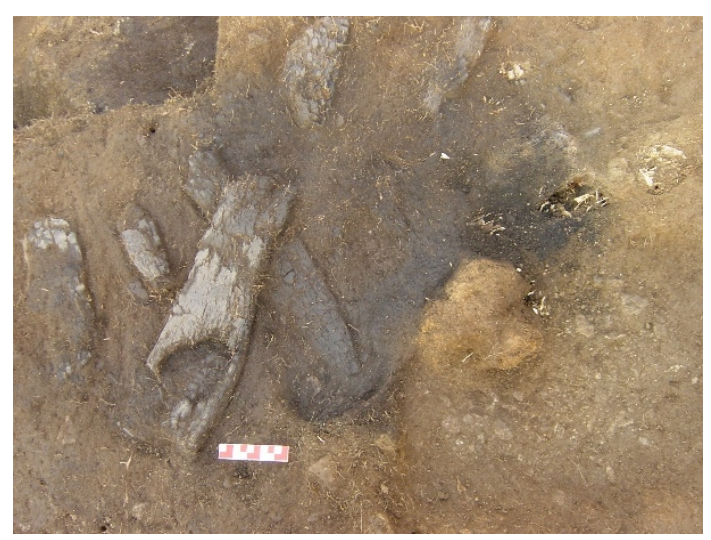

C

Fig. 8 a) Drawing of the woodcrafts recovered within the hearth during the excavation process of this feature, in the centre of the feature coloured in grey a rubified cobble and clay blocks in orange; $b$ and c) photographs of the woodcrafts during different stages of the excavation process. 


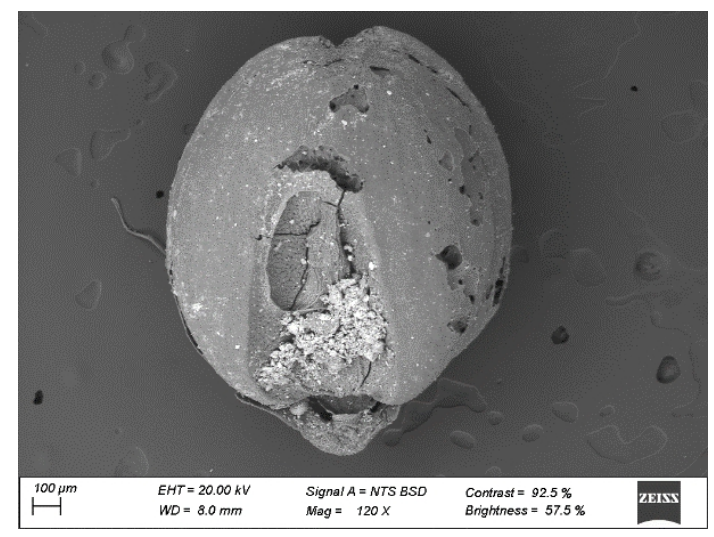

a
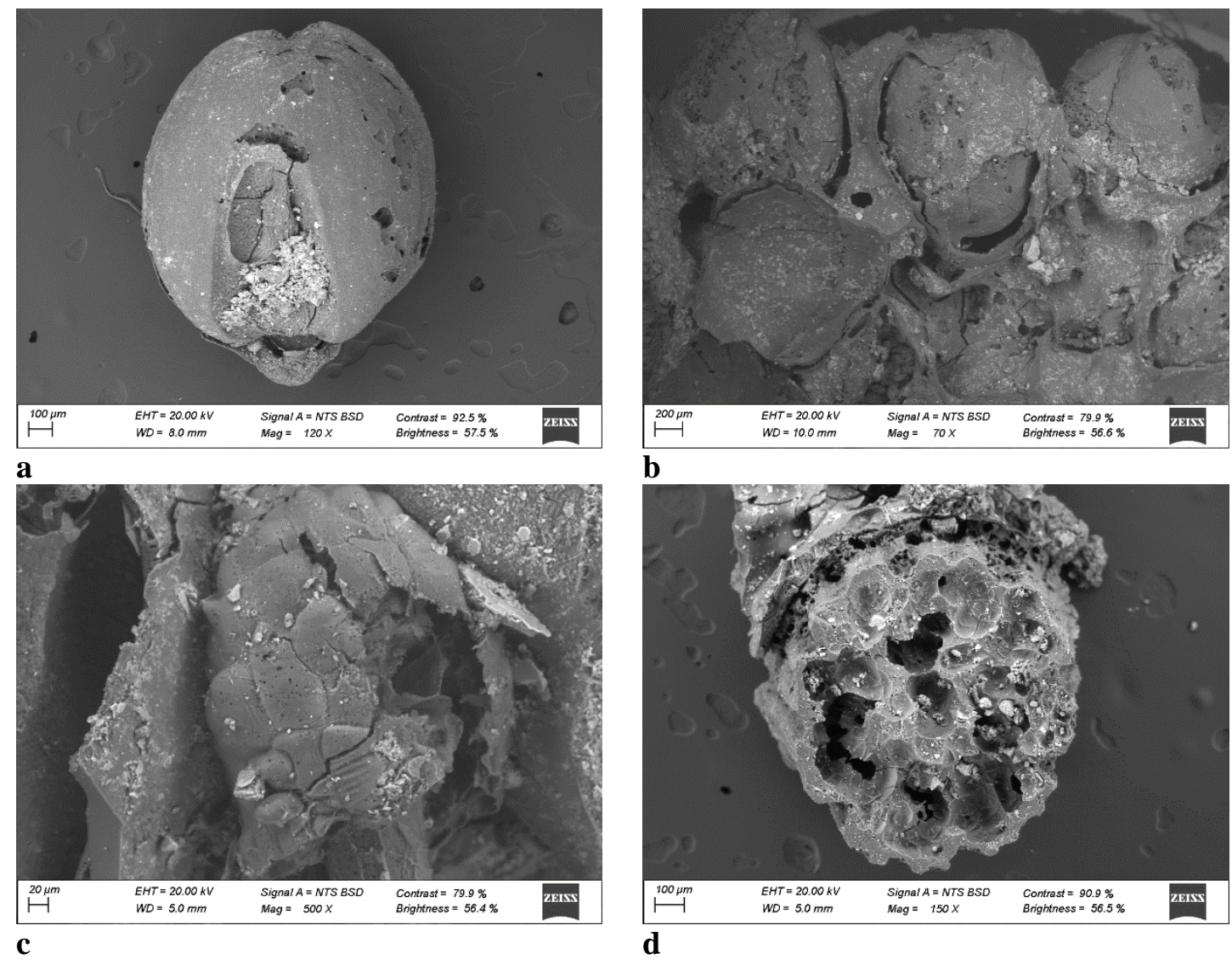

Fig. 9 Setaria italica seed (a), aggregated (b), vegetal structure (c) and stem (d). 


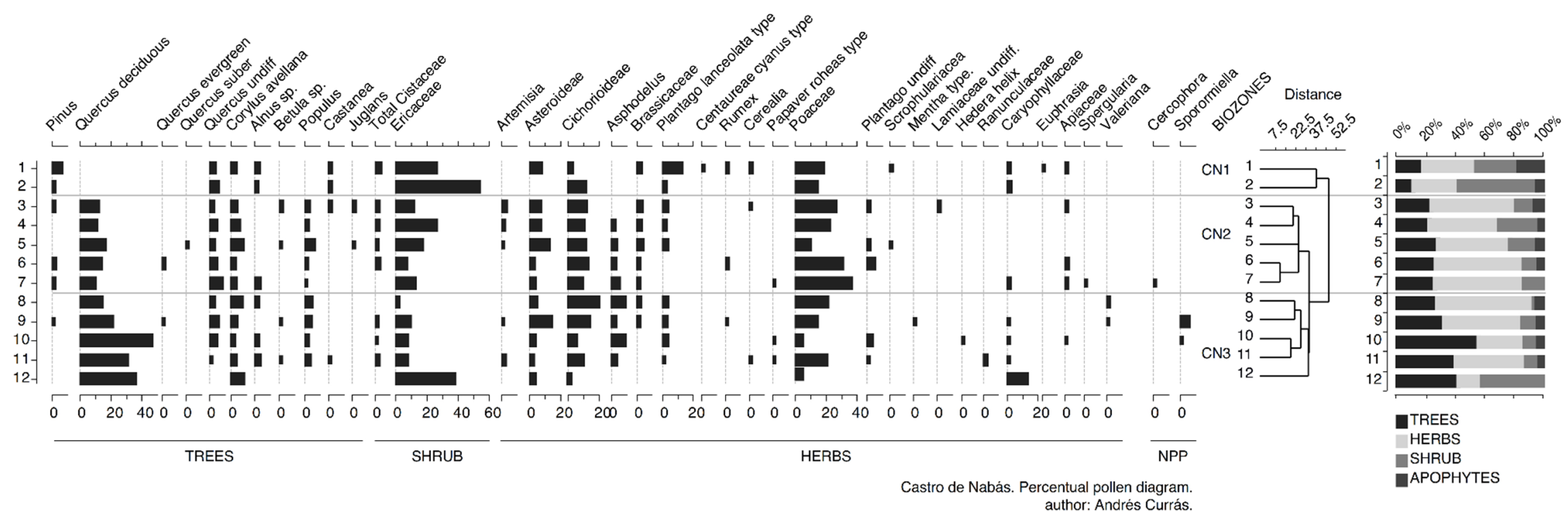

Fig. 10 Percentual pollen diagram, at the left it is indicated the code of the samples (author: Andrés Currás). 


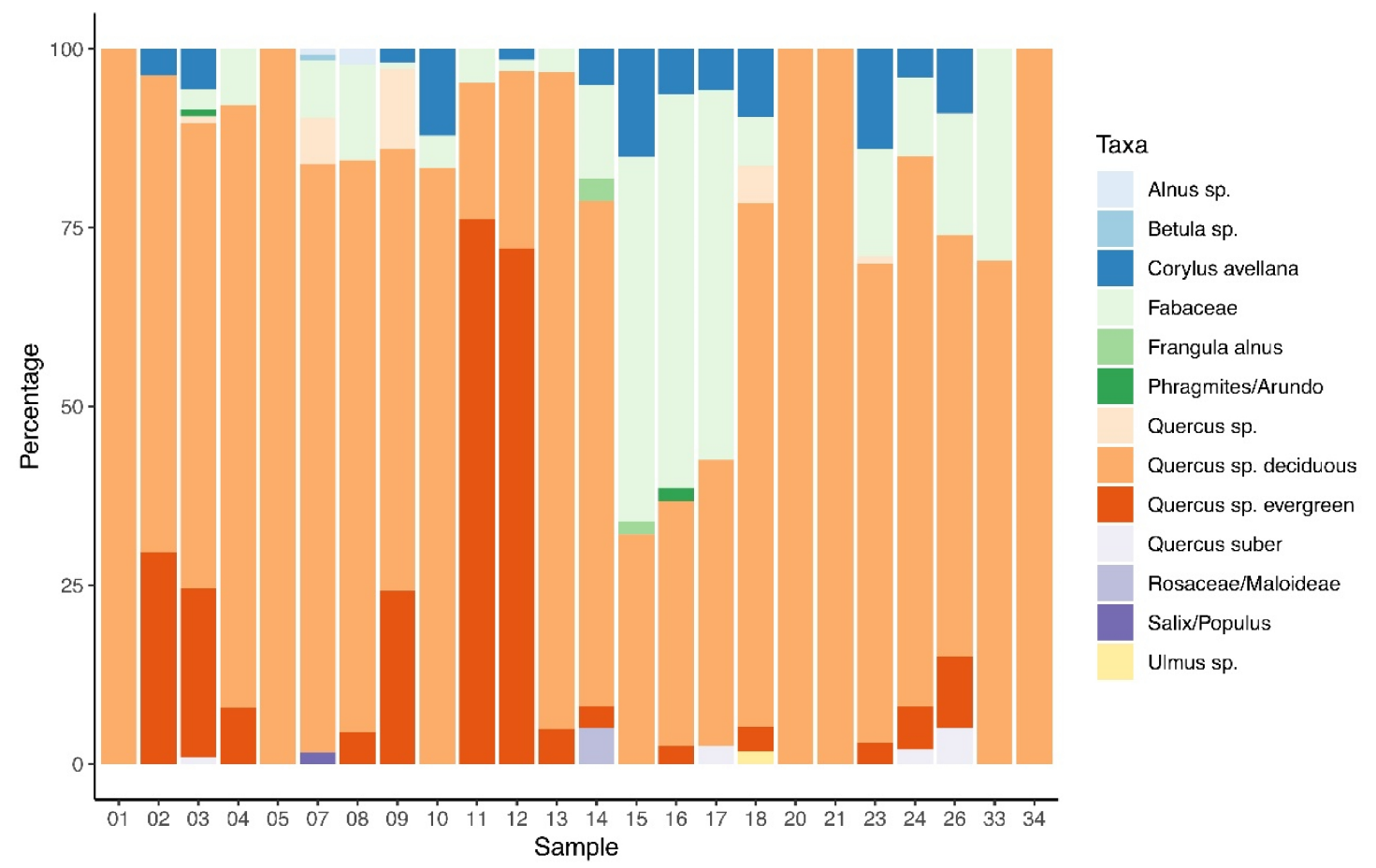

Fig. 11 Percentage of taxa presence across the different samples analysed in this paper. 


\begin{tabular}{ccccc}
\hline $\begin{array}{c}\text { Stratigraphic } \\
\text { Unit }\end{array}$ & $\begin{array}{c}\text { Conventional } \\
\text { radiocarbon age }\end{array}$ & $\begin{array}{c}\text { 2 Sigma calibrated } \\
\text { result } \mathbf{( 9 5 . 4 \%} \text { prob.) }\end{array}$ & $\begin{array}{c}\text { Laboratory } \\
\text { reference }\end{array}$ & Material \\
\hline 017 & $2080 \pm 25 \mathrm{BP}$ & $176-41 \mathrm{cal}$. BC & CNA-1080 & Seed \\
055 & $2041 \pm 28 \mathrm{BP}$ & 162 cal. BC-25 cal. AD & CSIC-2081 & Charcoal \\
\hline
\end{tabular}

Table 1. ${ }^{14} \mathrm{C}$ dates calibrated using Oxcal 4.2 (curve IntCal 13) (Reimer et al. 2013). 


\begin{tabular}{|c|c|c|c|c|c|c|}
\hline SU & Code & Recovery method & Type of processing & Litres & Macro-remains & Sampling \\
\hline \multirow[t]{16}{*}{12} & 02 & Handpicked sample & - & - & Charcoal & Complete \\
\hline & 03 & Bulk sample & Water sieved & 10 & Charcoal/Seeds & Sub-sampled \\
\hline & 04 & Handpicked sample & - & - & Charcoal & Complete \\
\hline & 05 & Handpicked sample & - & - & Charcoal & Complete \\
\hline & 07 & Bulk sample & Water sieved & 30 & Charcoal/Seeds & Sub-sampled \\
\hline & 08 & Handpicked sample & - & - & Charcoal & Complete \\
\hline & 09 & Handpicked sample & - & - & Charcoal & Complete \\
\hline & 10 & Handpicked sample & - & - & Charcoal & Complete \\
\hline & 11 & Handpicked sample & - & - & Charcoal & Complete \\
\hline & 12 & Handpicked sample & - & - & Charcoal & Complete \\
\hline & 13 & Handpicked sample & - & - & Charcoal & Complete \\
\hline & 14 & Handpicked sample & - & - & Charcoal & Complete \\
\hline & 15 & Handpicked sample & - & - & Charcoal & Complete \\
\hline & 16 & Handpicked sample & - & - & Charcoal & Sub-sampled \\
\hline & 17 & Handpicked sample & - & - & Charcoal & Complete \\
\hline & 18 & Handpicked sample & - & - & Charcoal & Sub-sampled \\
\hline \multirow[t]{8}{*}{17} & 01 & Handpicked sample & - & - & Charcoal & Complete \\
\hline & 20 & Handpicked sample & - & - & Charcoal & Complete \\
\hline & 21 & Handpicked sample & - & - & Charcoal & Complete \\
\hline & 26 & Bulk sample & Water sieved & 35 & Charcoal/Seeds & Sub-sampled \\
\hline & 28 & Handpicked sample & - & - & Seeds & Sub-sampled \\
\hline & 29 & Bulk sample & Wash-over & 0.48 & Charcoal/Seeds & Sub-sampled \\
\hline & 33 & Handpicked sample & - & - & Charcoal & Complete \\
\hline & 34 & Handpicked sample & - & - & Charcoal & Complete \\
\hline \multirow[t]{2}{*}{18} & 23 & Handpicked sample & - & - & Charcoal & Sub-sampled \\
\hline & 24 & Bulk sample & Water sieved & 20 & Charcoal/Seeds & Sub-sampled \\
\hline
\end{tabular}

Table 2. Samples analysed: information of provenance, recovery method, type of processing, macro-remains recovered and sampling during analysis. 


\begin{tabular}{ll}
\hline Code & Depth $(\mathbf{c m})$. \\
\hline 01 & $0-2.5$ \\
02 & $2.5-7.5$ \\
03 & $7.5-13$ \\
04 & $13-18$ \\
05 & $18-23$ \\
06 & $23-26$ \\
07 & $26-28.5$ \\
08 & $28.5-34$ \\
09 & $34-38.5$ \\
10 & $38.5-43$ \\
11 & $43-47$ \\
12 & $47-50$ \\
\hline
\end{tabular}

Table 3. Code and depth of the pollen samples. 


\begin{tabular}{lcccc}
\hline \multicolumn{1}{c}{ Stratigraphic unit } & \multicolumn{2}{c}{$\mathbf{1 2}$} & $\mathbf{1 8}$ & $\mathbf{1 7}$ \\
$\quad$ Sample code & 03 & 07 & 24 & 26 \\
$\quad$ Sampling & S & S & S & S \\
\hline Quercus sp. deciduous & 69 & 102 & 77 & 59 \\
Quercus sp. evergreen & 25 & & 6 & 10 \\
Quercus suber (cork) & 1 & & 2 & 5 \\
Quercus sp. & 1 & 8 & & \\
Corylus avellana & 6 & & 4 & 9 \\
Fabaceae & 3 & 10 & 11 & 17 \\
Phragmites/Arundo & 1 & & & \\
Alnus sp. & & 1 & & \\
Betula sp. & & 1 & & \\
Salix/Populus & & 2 & & \\
TOTAL & 106 & 124 & 100 & 100 \\
\hline
\end{tabular}

Table 4. Charcoal identification of water sieved samples (S: sub-sampled). 


\begin{tabular}{|c|c|c|c|c|c|c|c|c|c|c|c|c|c|c|c|c|c|c|c|c|}
\hline Stratigraphic unit & & & & & & & & 12 & & & & & & & 18 & & & 17 & & \\
\hline Sample code & 02 & 04 & 05 & 08 & 09 & 10 & 11 & 12 & 13 & 14 & 15 & 16 & 17 & 18 & 23 & 01 & 20 & 21 & 33 & 34 \\
\hline Sampling & $\mathrm{C}$ & $\mathrm{C}$ & $\mathrm{C}$ & $\mathrm{C}$ & $\mathrm{C}$ & $\mathrm{C}$ & $\mathrm{C}$ & $\mathrm{C}$ & $\mathrm{C}$ & $\mathrm{C}$ & $\mathrm{C}$ & $S$ & $\mathrm{C}$ & $\mathrm{S}$ & $\mathrm{S}$ & $\mathrm{C}$ & $\mathrm{C}$ & $\mathrm{C}$ & $\mathrm{C}$ & $\mathrm{C}$ \\
\hline Quercus sp. deciduous & 36 & 43 & 1 & 36 & 66 & 55 & 4 & 32 & 56 & 70 & 17 & 54 & 48 & 85 & 67 & 4 & 1 & 1 & 19 & 1 \\
\hline Quercus sp. evergreen & 16 & 4 & & 2 & 26 & & 16 & 93 & 3 & 3 & & 4 & & 4 & 3 & & & & & \\
\hline Quercus suber (cork) & & & & & & & & & & & & & 3 & & & & & & & \\
\hline Quercus sp. & & & & & 12 & & & & & & & & & 6 & 1 & & & & & \\
\hline Fabaceae & & 4 & & 6 & 1 & 3 & 1 & 2 & 2 & 13 & 27 & 87 & 62 & 8 & 15 & & & & 8 & \\
\hline Corylus avellana & 2 & & & & 2 & 8 & & 2 & & 5 & 8 & 10 & 7 & 11 & 14 & & & & & \\
\hline Rosaceae/Maloideae & & & & & & & & & & 5 & & & & & & & & & & \\
\hline Phragmites/Arundo & & & & & & & & & & & & 3 & & & & & & & & \\
\hline Alnus sp. & & & & 1 & & & & & & & & & & & & & & & & \\
\hline Ulmus sp. & & & & & & & & & & & & & & 2 & & & & & & \\
\hline Frangula alnus & & & & & & & & & & 3 & 1 & & & & & & & & & \\
\hline TOTAL & 54 & 51 & 1 & 45 & 107 & 66 & 21 & 129 & 61 & 99 & 53 & 158 & 120 & 116 & 100 & 4 & 1 & 1 & 27 & 1 \\
\hline
\end{tabular}

Table 5. Charcoal identification of handpicked samples (C: complete; S: sub-sampled). 


\begin{tabular}{lcccccccc}
\hline \multicolumn{1}{c}{ Stratigraphic unit } & \multicolumn{2}{c}{$\mathbf{1 2}$} & & & \multicolumn{2}{c}{$\mathbf{1 7}$} \\
$\quad$ Taxa/Plant part & TW & ST & KN & BA & TW & ST & KN & BA \\
\hline Fabaceae & 33 & & & & 14 & & & \\
Corylus avellana & 24 & & & & 1 & & \\
$\begin{array}{l}\text { Quercus } \text { sp. deciduous } \\
\text { Alnus } \text { sp. }\end{array}$ & 5 & & 2 & & & & \\
$\begin{array}{l}\text { Quercus } \text { sp. } \\
\text { Phragmites/Arundo }\end{array}$ & 1 & & & & & & \\
Quercus suber & & 4 & 1 & & & & \\
\hline
\end{tabular}

Table 6. Plant part morphologically identified (TW: twig, ST: stem; KN: knot, BA: bark). 


\begin{tabular}{lcccccc}
\hline \multicolumn{1}{c}{ Stratigraphic unit } & & SU12 & \multicolumn{3}{c}{ SU17 } \\
$\quad$ Taxa/Diameter $(\mathrm{cm})$. & $0.4-0.9$ & $1-1.9$ & $2-2.9$ & $0.4-0.9$ & $1-1.9$ & $2-2.9$ \\
\hline Fabaceae & 4 & 13 & & 2 & 4 & 2 \\
$\begin{array}{l}\text { Corylus avellana } \\
\text { Quercus sp. deciduous }\end{array}$ & 4 & 9 & 1 & & & \\
Phragmites/Arundo & 3 & & 1 & & & \\
\hline
\end{tabular}

Table 7. Complete diameters of twigs and stems. 


\begin{tabular}{cccccccc}
\hline Sample & $\begin{array}{c}\text { Piece } \\
\text { N. }\end{array}$ & SU & $\begin{array}{c}\text { General } \\
\text { description }\end{array}$ & Category & Taxa & $\begin{array}{c}\text { Plant } \\
\text { part }\end{array}$ & $\begin{array}{c}\text { Support } \\
\text { extraction }\end{array}$ \\
\hline 22 & 3894 & 17 & Plank & Object & Quercus sp. deciduous & Trunk & N \\
27 & 3895 & 17 & Container? & Object & $\begin{array}{c}\text { Quercus suber } \\
\text { Cork }\end{array}$ & $\mathrm{F}$ \\
33 & 3893 & 17 & Plank & Object & $\begin{array}{c}\text { Quercus } \text { sp. deciduous } \\
\text { Trunk }\end{array}$ & $\mathrm{P}$ \\
& 3902 & 17 & Plank & Object & Quercus sp. deciduous & Trunk & $\mathrm{N}$ \\
& 3903 & 17 & Plank & Object & Quercus sp. deciduous & Trunk & $\mathrm{N}$ \\
& 3906 & 17 & Plank & Object & Quercus sp. deciduous & Trunk & $\mathrm{N}$ \\
& 3904 & 17 & Plank & Object & Quercus sp. evergreen & Trunk & P \\
& 3905 & 17 & Plank & Object & Quercus sp. evergreen & Trunk & $\mathrm{N}$ \\
& 3892 & 17 & Hook? & Object & Quercus sp. deciduous & Twig & E \\
\hline
\end{tabular}

Table 8. Description of carbonised woodcrafts. 


\begin{tabular}{|c|c|c|c|c|c|c|c|c|c|c|c|c|}
\hline \multirow{4}{*}{$\begin{array}{c}\text { Stratigraphic unit } \\
\text { Sample code } \\
\text { Recovery method } \\
\text { Individuals / Weight (g.) }\end{array}$} & \multicolumn{4}{|c|}{12} & \multicolumn{2}{|c|}{18} & \multicolumn{6}{|c|}{17} \\
\hline & \multirow{2}{*}{\multicolumn{2}{|c|}{$\begin{array}{c}3 \\
\mathrm{WS}\end{array}$}} & \multirow{2}{*}{\multicolumn{2}{|c|}{$\begin{array}{c}7 \\
\text { WS }\end{array}$}} & \multirow{2}{*}{\multicolumn{2}{|c|}{$\begin{array}{c}24 \\
\text { WS }\end{array}$}} & \multirow{2}{*}{\multicolumn{2}{|c|}{$\begin{array}{c}26 \\
\text { WS }\end{array}$}} & \multirow{2}{*}{\multicolumn{2}{|c|}{$\begin{array}{l}28 \\
\mathrm{HP}\end{array}$}} & \multirow{2}{*}{\multicolumn{2}{|c|}{$\begin{array}{c}29 \\
\text { WO }\end{array}$}} \\
\hline & & & & & & & & & & & & \\
\hline & I & W & I & W & I & $\mathbf{W}$ & I & $\mathbf{W}$ & I & W & I & W \\
\hline $\begin{array}{l}\text { Setaria italica } \\
\text { Hordeum vulgare }\end{array}$ & 4 & 0.009 & $\begin{array}{c}30 \\
1\end{array}$ & $\begin{array}{l}0.469 \\
0.011\end{array}$ & 6 & 0.014 & 94 & 3.141 & 170,464 & 181.172 & 14,559 & 16,716 \\
\hline TOTAL & 4 & 0.009 & 31 & 0.480 & 6 & 0.014 & 94 & 3.141 & 170,464 & 181.172 & 14,559 & 16.716 \\
\hline
\end{tabular}

Table 9. Carpological identification of samples recovered by WS: water sieving, WO: wash-over sieving and HP: handpicking. 
ESM 1.

Results of the Statistical Analysis of Charcoal Samples

The richness analysis of the different samples shows how Sample 03 (7 taxa) and Samples 07, 14 and 18 ( 6 taxa) provided the highest taxonomic variability (ESM 2). For their part, Shannon's and Simpson's diversity indices point respectively to Samples 26 and 15 as those most diverse. Although richness, Shannon's and Simpson's are highly correlated with the sample size (coefficients of $0.87,0.81$ and 0.76 , respectively), none of them identifies the largest sample (Sample 16) as the most diverse. Regarding the Pielou's evenness index, it suggests that Samples 33, 15 and 26 are those in which the taxa are more evenly distributed, while Sample 03, which had the highest number of taxa $(n=7)$, shows a relatively modest evenness index, probably due to the marked predominance of Quercus sp. over the other taxa (Fig. 11).

Figure available in ESM 5 is the graphical expression of the variability detected in the samples. This figure displays the relationship between Shannon's diversity index and Pielou's J evenness index, classifying the different samples according to their size (more or less than 100 fragments) and recovery method (bulk sample versus handpicked sample). The higher presence of smaller samples on the left side of the vertical line that marks the median reflects the aforementioned strong correlation between Shannon's index and sample size. There are, however, some exceptions to this behaviour, such as Sample 15, Sample 14 and, to a lesser extent, Sample 02, which show a relatively high Shannon's entropy despite their smaller size. Meanwhile, and although three of the four bulk samples are located in the lower half of the $y$ axis defined by the median, the Pielou's index does not show a clear dependence upon either sample size or recovery method.

These results suggest that size, and not recovery method, is the main reason behind the differences between the samples analysed in this paper. In fact, if the differences between bulk and handpicked samples regarding the different taxa are checked (ESM 3), it shows how, when comparing the complete samples (including the smaller ones), the Mann-Whitney-Wilcoxon test shows the existence of significant differences both at a global level and in specific taxa such as Fabaceae, Quercus sp. deciduous and Quercus sp. evergreen. However, when only the larger samples ( $\geq 99$ fragments) are taken into account, the differences disappear. Something similar happens when exploring the statistical differences between the diversity indices of bulk and handpicked samples (ESM 4). Again, richness shows statistically significant differences when comparing the complete samples, but not when analysing only the larger samples.

Taking into consideration the apparent impact that size seems to have had on taxa richness, we decided to explore this relationship in more depth to see if size was the only cause behind the variability of the samples. Different linear and nonlinear models (linear, logarithmic, asymptotic, etc.) were compared against the actual distribution of our data, and the asymptotic regression model was selected due its lower deviance and due to the fact that the curve fitted the distribution relatively well (ESM 6, red dash line). A Monte-Carlo prediction/confidence interval was created for this model using the data of 100,000 simulations (ESM 6, grey smoothed area). The model shows how the taxa richness in many of our samples (especially the smaller ones) is similar to that expected in collections of the same size. However, there are other samples that show a theoretical higher or lower richness than the one predicted by the model. Thus, Samples 03, 07, 14 or 18 show a theoretical higher richness, while Samples 10, 12, 13 or 17 (among others) contain less taxa than expected. 
A second approach implied the calculation of rarefaction curves and their $95 \%$ confidence interval for our samples. The results (ESM 7) suggest a different scenario than the previous model, with all the samples, except Sample 03, showing a lower richness than that predicted by the rarefaction curve (red dash line). However, the 95\% confidence interval suggests that the taxa richness of most of our samples is in relatively good agreement with that expected for sets of the same size, with the exception of, among others, Samples $02,10,12,13$ or 17, the richness of which is lower than predicted. 
ESM 2.

Characteristics of the charcoal samples considered in this paper

\begin{tabular}{lllllll}
\hline Sample & Recovery method & Fragments & Richness & Shannon & Simpson & Pielou \\
\hline 01 & Handpicked sample & 4 & 1 & 0 & 0 & 0 \\
02 & Handpicked sample & 54 & 3 & 0.75279153 & 0.46639232 & 0.68522038 \\
03 & Bulk sample & 106 & 7 & 1.01559345 & 0.51637593 & 0.52191179 \\
04 & Handpicked sample & 51 & 3 & 0.54315975 & 0.27681661 & 0.49440531 \\
05 & Handpicked sample & 1 & 1 & 0 & 0 & 0 \\
07 & Bulk sample & 124 & 6 & 0.68483879 & 0.31230489 & 0.3822158 \\
08 & Handpicked sample & 45 & 4 & 0.67013954 & 0.33975309 & 0.48340349 \\
09 & Handpicked sample & 107 & 5 & 1.00523167 & 0.5474714 & 0.62458555 \\
10 & Handpicked sample & 66 & 3 & 0.54821998 & 0.28879706 & 0.49901133 \\
11 & Handpicked sample & 21 & 3 & 0.66801782 & 0.38095238 & 0.60805602 \\
12 & Handpicked sample & 129 & 4 & 0.71091403 & 0.4182441 & 0.51281607 \\
13 & Handpicked sample & 61 & 3 & 0.33871278 & 0.15372212 & 0.30830966 \\
14 & Handpicked sample & 99 & 6 & 1.02516974 & 0.47586981 & 0.57215812 \\
15 & Handpicked sample & 53 & 4 & 1.06863617 & 0.61445354 & 0.77085805 \\
16 & Handpicked sample & 158 & 5 & 1.03850636 & 0.57498798 & 0.64526028 \\
17 & Handpicked sample & 120 & 4 & 0.96568184 & 0.56902778 & 0.6965922 \\
18 & Handpicked sample & 116 & 6 & 0.97497152 & 0.44515458 & 0.54414197 \\
20 & Handpicked sample & 1 & 1 & 0 & 0 & 0 \\
21 & Handpicked sample & 1 & 1 & 0 & 0 & 0 \\
23 & Handpicked sample & 100 & 5 & 0.97939221 & 0.508 & 0.60853059 \\
24 & Bulk sample & 100 & 5 & 0.81985125 & 0.3894 & 0.50940222 \\
26 & Bulk sample & 100 & 5 & 1.20929621 & 0.6024 & 0.75137798 \\
33 & Handpicked sample & 27 & 2 & 0.60769342 & 0.4170096 & 0.87671629 \\
34 & Handpicked sample & 1 & 1 & 0 & 0 & 0 \\
\hline & & & & & & \\
\hline
\end{tabular}


ESM 3.

Results of the Mann-Whitney-Wilcoxon test applied to the complete samples and only to those samples larger than 99 fragments in order to detect differences in taxa composition according to the method used during the recovery (bulk versus handpicked). * Statistically significant at a 95\% level.

\begin{tabular}{lllll}
\hline Taxa & \multicolumn{2}{l}{ Complete Samples } & \multicolumn{2}{l}{ Reduced ( $\geq 99)$} \\
& MWW & P-VALUE & MWW & P-VALUE \\
TOTAL & 40000 & $0.000001^{*}$ & 9000 & 0.06 \\
\hline Alnus sp. & 300 & 1 & 70 & 0.4 \\
Betula sp. & 300 & 0.3 & 70 & 0.4 \\
Corylus avellana & 200 & 0.3 & 40 & 0.1 \\
Fabaceae & 200 & $0.007^{*}$ & 40 & 0.2 \\
Frangula alnus & 200 & 0.2 & 60 & 0.4 \\
Phragmites / Arundo & 300 & 1 & 60 & 1 \\
Quercus sp. & 300 & 0.6 & 50 & 0.6 \\
Quercus sp. deciduous & 100 & $0.0005^{*}$ & 50 & 0.5 \\
Quercus sp. evergreen & 200 & $0.02^{*}$ & 50 & 0.3 \\
Quercus suber & 300 & 0.3 & 70 & 0.3 \\
Rosaceae / Maloideae & 300 & 0.3 & 60 & 0.4 \\
Salix / Populus & 300 & 0.3 & 70 & 0.4 \\
Ulmus sp. & 300 & 0.3 & 60 & 0.4 \\
\hline
\end{tabular}


ESM 4.

Results of the Mann-Whitney-Wilcoxon and t-student tests applied to the complete samples and only to those samples larger than 99 fragments in order to detect differences in taxa diversity according to the method used during the recovery (bulk versus handpicked). * Statistically significant at a $95 \%$ level.

\begin{tabular}{|c|c|c|c|c|}
\hline & \multicolumn{2}{|c|}{ Complete sample } & \multicolumn{2}{|c|}{ Reduced ( $\geq 99$ ) } \\
\hline & $\mathrm{MWW} / \mathrm{t}$ & $p$-value & $\mathrm{MWW} / \mathrm{t}$ & p-value \\
\hline Richness & $4(t)$ & $0.04 *$ & $1(t)$ & 0.2 \\
\hline Shannon & 60 & 0.1 & $-0.2(\mathrm{t})$ & 0.8 \\
\hline Simpson & 50 & 0.3 & $-0.7(t)$ & 0.5 \\
\hline Pielou & 20 & 0.5 & $-0.7(t)$ & 0.5 \\
\hline
\end{tabular}


ESM 5.

Shannon's diversity index and Pielou's J evenness index of the samples considered in this paper, according to their recovery method and size (number of fragments)

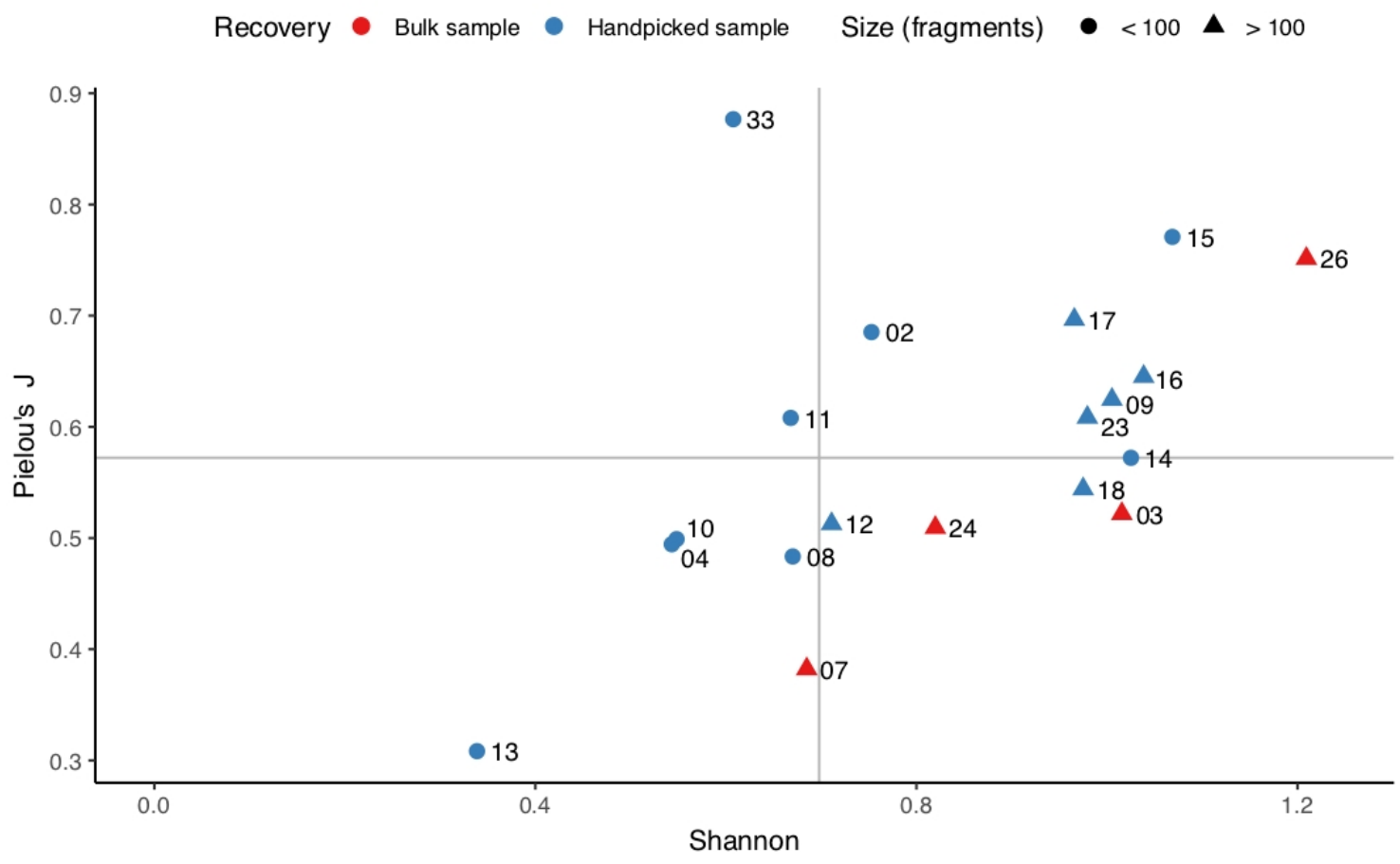


ESM 6.

Asymptotic regression model of expected richness according to sample size. The smooth area is a Monte-Carlo prediction/confidence interval created using the data obtained in $100 \mathrm{k}$ simulations

Recovery Bulk sample Handpicked sample

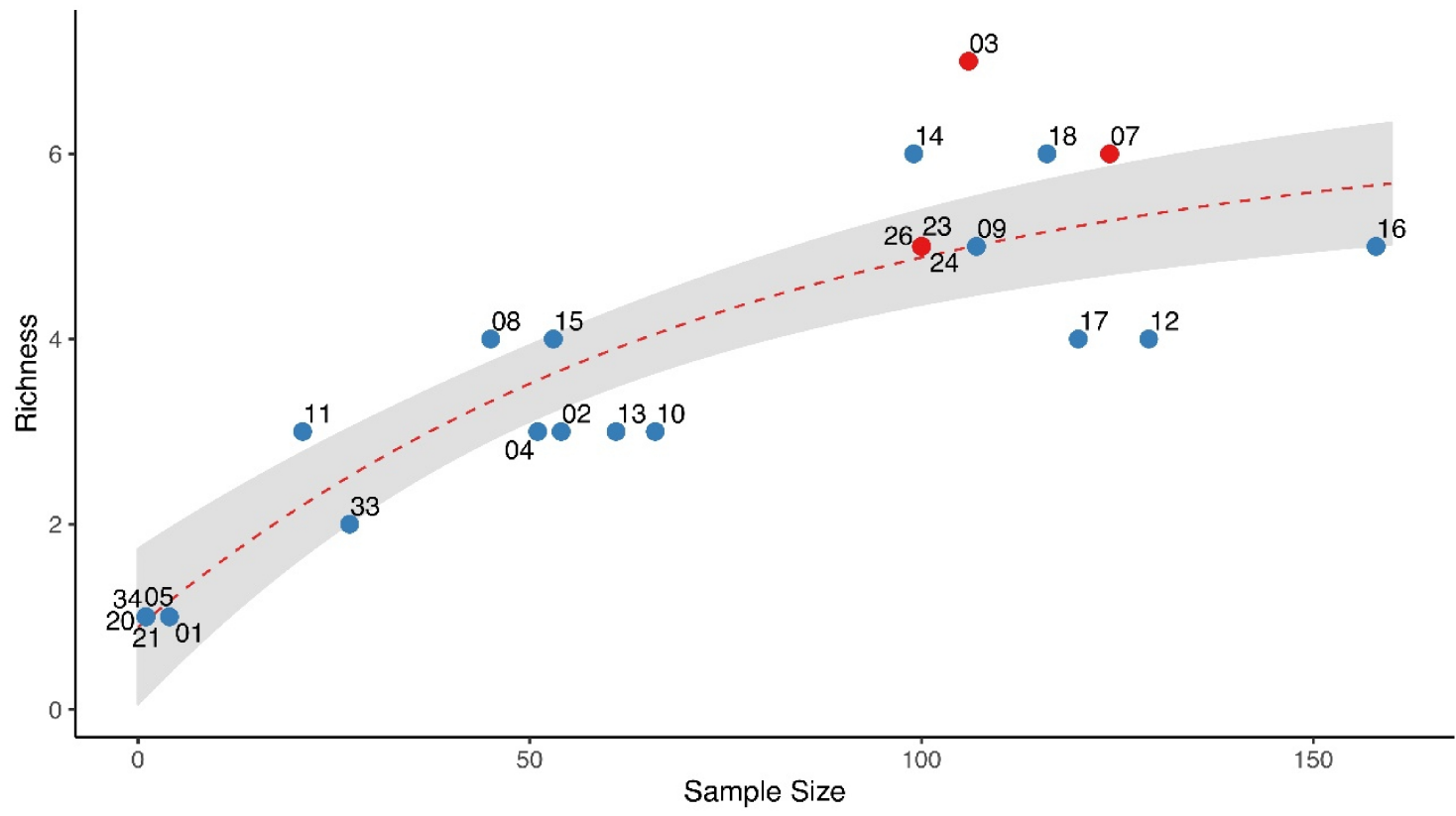


ESM 7.

Rarefaction curve and 95\% confidence interval of the expected richness according to sample size

Recovery Bulk sample Handpicked sample

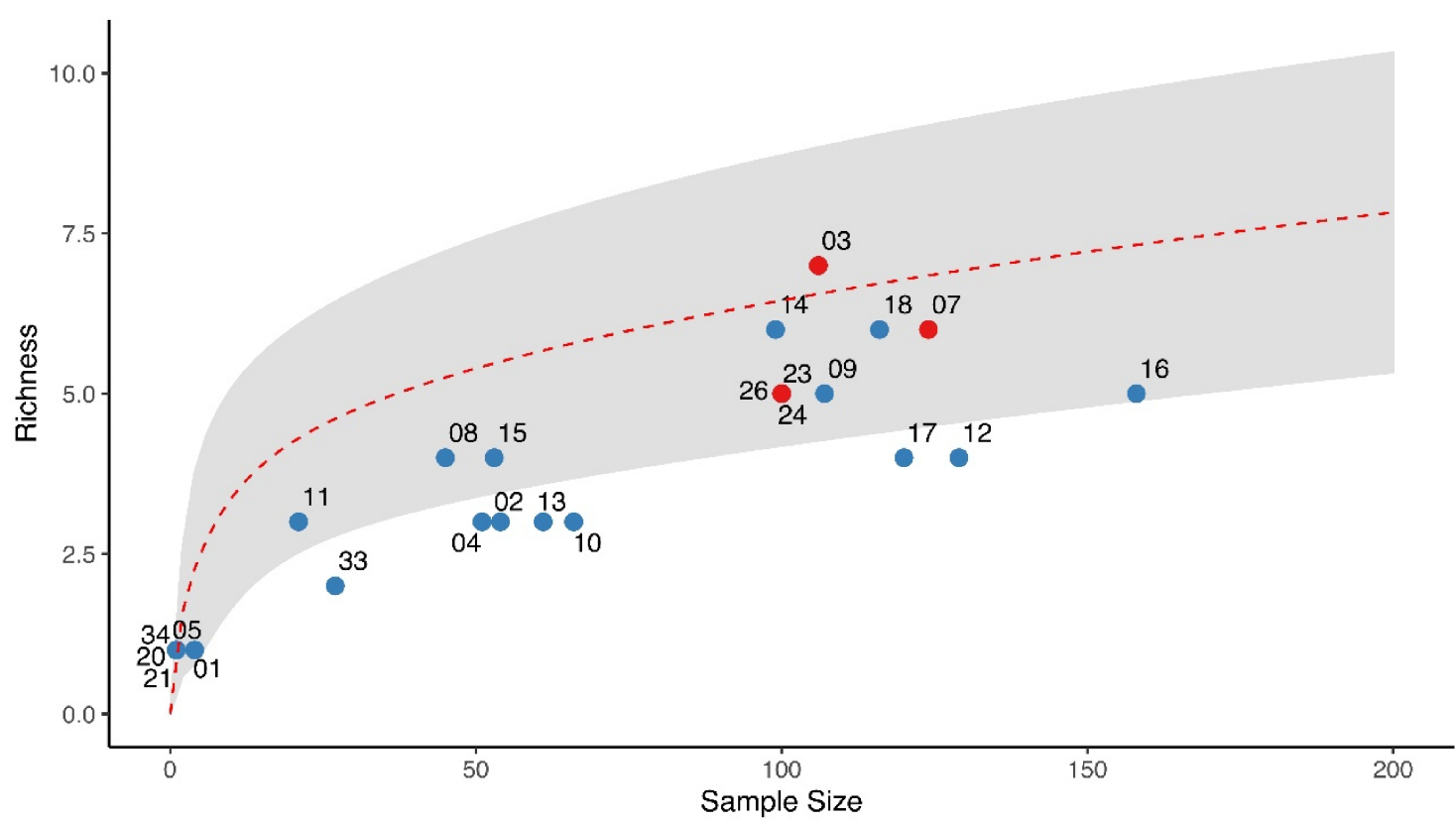


ESM 8.

Discussion of taphonomical aspects related to pollen samples

Charcoal and pollen analyses provide complementary information about past vegetation, although we must always proceed with caution when interpreting landscape evolution as indicated by pollen percentages recovered from archaeological sediment. In contrast to the records preserved in natural deposits such as wetlands or lakes, pollen input in such a context may result either from regional vegetation change or local on-site manipulation of plants by humans (Fægri and Iversen 1989). In addition, the pollen record was recovered from a sedimentary deposit that was placed on the natural surface to create a level foundation for the paved floor of the roundhouse. This sediment was probably gathered in the surroundings, and it was transported and deposited inside the structure, a feature which adds some chronological uncertainty regarding pollen deposition, because differences between the pollen content of the samples could be related to different areas of soil procurement or even to an inverse stratigraphy. Despite this limitation directly related to the formation process of this deposit, it is interesting to note that this profile was sealed when the roundhouse was built.

Samples 12 to 8 indicate that the provenance of these sediments was likely from a forested landscape dominated by deciduous oak and other mesophilous trees with low values of Poaceae. Heath shrub, as suggested by the occurrence of Ericaceae and Cistaceae is attested but its presence is not relevant when compared to other taxa. The presence of crops in the area where these sediments were gathered may be suggested by pollen found in sample 11 , but due to its low occurrence within the wider assemblage, this should only be considered a hypothesis at present.

Samples 9 and 8 show a lower proportion of oak pollen coeval with the occurrence of nitrophylous and heliophilous pollen taxa such as Asteroideae, Cichorioideae and Papaver, which suggests human activity and some degree of land use. The lower representation of forest species in both samples could be explained by a different provenance of the sediment, for instance, from an area where herbaceous vegetation was widespread. Although the latter cannot be fully discounted, the formation of this archaeological deposit could have taken place under a new context, for instance, more intensive land use.

The samples 7 to 3 suggest their provenance from a landscape with a lower proportion of oak, a higher abundance of grasslands and the occurrence of mesophilous vegetation, such as hazelnut and Populus. The higher presence of heliophilous vegetation, such as Asphodelus, Brassicaceae and Apiaceae, supply further evidence of an open landscape, supported also by the higher proportion of nitrophilous plants growing in perturbed soils, as indicated by Asteroideae, Cichorioideae, Plantago lanceaolata and Rumex.

The presence of coprophilous fungal spores in samples 10, 9 and 7 could provide some evidence of grazing activity in the area where this sediment was collected or of the presence of local fauna. Nevertheless, such a minor occurrence prevents the corroboration of herding activities in a more consistent manner. A rather similar conclusion can be obtained regarding the relevance of crops around the area. Considering that cereal pollen production is scarce and low dispersing (Vuorela 1973; Hall 1988), its occurrence in samples 11 and 3 may attest the local presence of cereals near the sediment. 
The presence of Castanea and Juglans in the pollen assemblage could be indicative of small local stands or at least some specimens of these trees in the environs of Nabás. Their pollen is commonly included as an anthropogenic pollen indicator of human activity (Bottema and Woldring 1990), although their occurrence can be interpreted as result of cultivation only in the regions where refugia did not exist (López-Merino et al. 2010). The economic importance of these trees is related to their edible fruits and timber (Mercuri et al. 2013). The exploitation of Juglans wood has been attested in northwest Iberia since the Late Bronze Age (Figueiral 2000, 2001) and during the Iron Age: As Ermidas (Vila Nova de Famalicão) (Figueiral 1996), Castrolandín (Cuntis, Pontevedra) (Martín-Seijo 2008a) and El Castrelín de San Juan de Paluezas (Borrenes, León) (López-Merino et al. 2009, 2010, Reher et al. 2012). The presence of Castanea wood is less frequent but was recorded at the site of Castro Grande de O Neixón (Boiro, A Coruña) (Martín-Seijo 2008b).

Bottema S, Woldring $\mathrm{H}$ (1990) Anthropogenic indicators in the pollen record of the Eastern Mediterranean. In: Bottema S, Entjes-Nieborg G, van Zeist W (eds) Handbook of Man's Role in the Shaping of the Eastern Mediterranean Landscape. Rotterdam, Balkema, pp. 231-264.

Faegri K, Iversen J (1989) Textbook of Pollen Analysis, fourth ed. New Jersey The Blackburn Press.

Figueiral I (1996) Wood resources in north-west Portugal: their availability and use from the late Bronze Age to the Roman period. Veg Hist Archaeobot 5 (1-2): 121-129.

Figueiral, I. (2000). O povoado de S. Juliâo (Vila Verde, Braga): contributos da antracologia. In: Bettencourt AMS O povoado de Sâo Juliâo, Vila Verde, Norte de Portugal, nos finais da Idade do Bronze e na transiçâo para a Idade do Ferro. Braga, Univ. do Minho-Instituto de Ciências Sociais, Anexo I.

Figueiral I (2001) O povoado da Santinha (Amares, Braga). O contributo da antracologia. In: Bettencourt AMS O povoado da Santinha, Amares, Norte de Portugal, nos finais da Idade do Bronze. Braga, Univ. do Minho-Instituto de Ciências Sociais, Anexo I.

Hall V (1988) The role of harvesting Techniques in the Dispersal of Pollen Grains of Cerealia. Pollen et Spores, 30: 265-270.

López-Merino L, López-Sáez JA, Sánchez-Palencia FJ, Reher GS, Pérez S (2009) Castaños, nogales y cereales: la antropización de los paisajes de Asturias y León en época romana. Actas de la III Reunión sobre Historia Forestal. Cuadernos de la Sociedad Española de Ciencias Forestales, 30 : 93-99.

López-Merino L, Peña-Chocarro L, Ruiz-Alonso M, López-Sáez JA, Sánchez-Palencia FJ (2010) Beyond nature: the management of a productive cultural landscape in Las Médulas area (EI Bierzo, León, Spain) during pre-Roman and Roman times. Plant Biosyst 144 (4): 909-923. 10.1080/11263504.2010.491976

Martín-Seijo M (2008a) Os combustibles e as manufacturas en madeira durante a Idade do Ferro: estudo antracolóxico do xacemento de Castrolandín (Cuntis, Pontevedra). Estudos do Quaternário 5: 87-98. 
Martín-Seijo M (2008b). Estudo de carbóns e madeiras: paleoambiente, xestión forestal e explotación de combustible". In: Ayán XM (coord) Os Castros de Neixón II. Noia Ed. ToxosOutos, pp. 249-267.

Mercuri AM, Mazzanti MB, Florenzano A, Montecchi MC, Rattighieri E (2013) Olea, Juglans and Castanea: the OJC group as pollen evidence of the development of human-induced environments in the Italian peninsula. Quat Int, 303: 24-42. http://dx.doi.org/10.1016/j.quaint.2013.01.005

Reher GS, López-Merino L, Sánchez-Palencia FJ, López-Sáez JA (2012) Configuring the landscape: Roman mining in the conventus Asturum (NW Hispania). In: Kluiving $S$ and Guttmann-Bond $E$ (eds) Landscape Archaeology between Art and Science. From a Multi-to an Interdisciplinary Approach. Amsterdam, Amsterdam University Press. pp. 127-136

Vuorela I (1973) Relative pollen rain around cultivated fields. Acta Botannica Fennica 102: 1-27. 